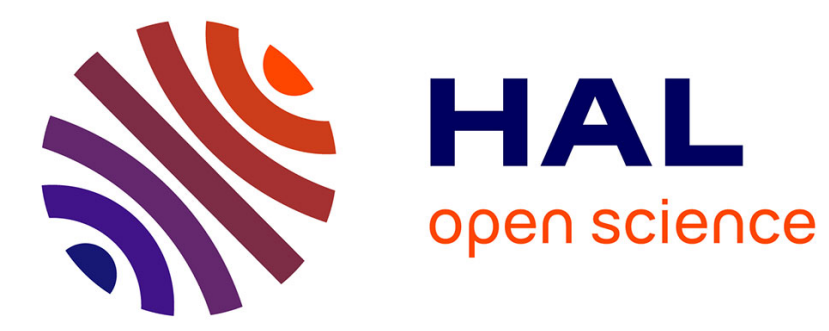

\title{
GHG emissions and fossil energy use as consequences of efforts of improving human well-being in Africa
}

\author{
Laté Ayao Lawson
}

\section{To cite this version:}

Laté Ayao Lawson. GHG emissions and fossil energy use as consequences of efforts of improving human well-being in Africa. Journal of Environmental Management, 2020, 273 (1), pp.111136. 10.1016/j.jenvman.2020.111136 . hal-03165372v2

\section{HAL Id: hal-03165372 \\ https://hal.inrae.fr/hal-03165372v2}

Submitted on 7 Apr 2023

HAL is a multi-disciplinary open access archive for the deposit and dissemination of scientific research documents, whether they are published or not. The documents may come from teaching and research institutions in France or abroad, or from public or private research centers.
L'archive ouverte pluridisciplinaire HAL, est destinée au dépôt et à la diffusion de documents scientifiques de niveau recherche, publiés ou non, émanant des établissements d'enseignement et de recherche français ou étrangers, des laboratoires publics ou privés. 


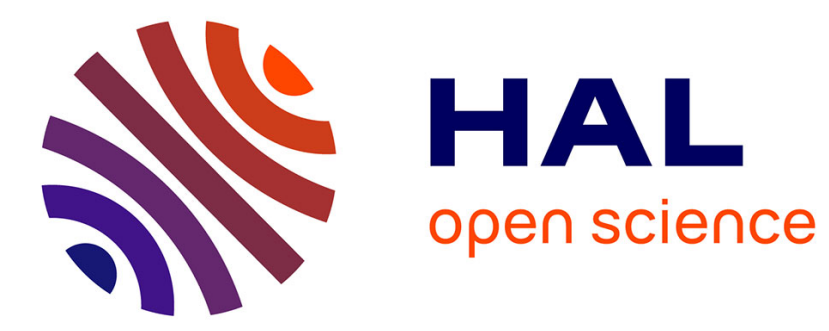

\title{
GHG emissions and fossil energy use as consequences of efforts of improving human well-being in Africa
}

\author{
Laté Ayao Lawson
}

\section{To cite this version:}

Laté Ayao Lawson. GHG emissions and fossil energy use as consequences of efforts of improving human well-being in Africa. 2020. hal-02899124

\section{HAL Id: hal-02899124 \\ https://hal.science/hal-02899124}

Preprint submitted on 14 Jul 2020

HAL is a multi-disciplinary open access archive for the deposit and dissemination of scientific research documents, whether they are published or not. The documents may come from teaching and research institutions in France or abroad, or from public or private research centers.
L'archive ouverte pluridisciplinaire HAL, est destinée au dépôt et à la diffusion de documents scientifiques de niveau recherche, publiés ou non, émanant des établissements d'enseignement et de recherche français ou étrangers, des laboratoires publics ou privés. 


\title{
GHG emissions and fossil energy use as consequences of efforts of improving human well-being in Africa
}

\author{
Laté A., Lawson \\ BETA, CNRS, INRAE \& University of Strasbourg
}

\begin{abstract}
This paper assesses the relationship between greenhouse gas emissions, fossil energy use and economic development, arguing that human development is not responsible for carbon dioxide emissions. To address the mechanism through which the latter relationship operates, a recursive system of three equations is estimated. The empirical results for a sample of 41 Sub-Saharan African countries observed over the period from 1990 to 2013 support our reasoning. Specifically, contrary to causality analyses which imply economic growth causing pollution, our recursive analysis indicates that greenhouse gas emissions are direct consequences of fossil energy use. Thus, economic growth is not to blame for carbon dioxide emissions. In terms of environmental policy for African countries, this study encourages efforts towards less polluting and renewable energies supply as well as investments in energy efficient technologies.
\end{abstract}

\section{KEYWORDS}

Human development, $\mathrm{CO}_{2}$ emissions, fossil energies, recursive modelling, spillovers.

\section{Introduction}

Anthropogenic pressures, greenhouse gas (GHG) emissions and resulting environmental changes have motivated systematic studies on the human-nature dynamics. In environmental economics for instance, the relationship between pollutant emissions, energy use and economic growth is one of the most exhaustively discussed subjects. Thereby, economic growth is often identified among the drivers of environmental degradation. This has been the case in the recent studies by Bedir and Yilmaz (2016), Mardani et al. (2019) and Rafindadi and Usman (2019) on carbon dioxide $\left(\mathrm{CO}_{2}\right)$, where by directly linking GHG emissions to income level, these studies state that economic growth causes $\mathrm{CO}_{2}$ emissions. Such a perspective, largely encountered in existing literature, fails to describe the mechanism through which the GHG emissions, energy and development nexus operates. This paper proposes a reassessment of the latter relationship for a sample of Sub-Saharan African (SSA) countries.

African countries are mostly endowed in mineral and energy resources and largely rely on the latter. While recent awareness on environmental pollution and climate change motivates global efforts in reducing fossil energies use, a continuous decline in renewable energy use is noted across SSA over the last 20 years (World Bank, 2020). Moreover, energy supply in Africa predominantly results from coal, oil and gas (Africa 
Energy Outlook, 2019), the consequences of which in terms of GHG emissions are well documented (Conti et al., 2016). Simultaneously, increasing access to electricity, life expectancy and school enrolment are observed (see Figures A.4, A.5 and A.6), motivating the question whether efforts of improving living conditions and human development finally resolve into fossil energy use in Africa. Though entire Africa is estimated to be responsible of circa $4 \%$ of the global $\mathrm{CO}_{2}$ emissions (Sy, 2016), population growth, macroeconomic performances, increasing access to electricity and fossil energy consumption presume growing GHG emissions. In this context, we analyse the human development, energy and GHG emissions nexus for African countries, relying on three arguments.

Firstly, it is to observe, if economic production largely utilises renewable energies, economic development will not be identified as a driver of GHG emissions. Therefore, this paper realistically argues that economic growth is not to blame for pollutant emissions, whereas fossil energy use is. Discussing the causes of $\mathrm{CO}_{2}$ emissions, it is essential to decouple economic growth from fossil energy use, since such a consideration will dictate environmental policies. For instance, assuming economic growth to be responsible for pollutant emissions justifies perspectives towards a 'de-growth' as a viable environmental policy. To the contrary, holding fossil energies use (and not economic growth) as a direct driver of GHG emissions promotes policies toward energy efficiency or energy transition. These observations motivate the present analysis in reconsidering the relationship between GHG emissions, energy and development. As described below (Figure 1), $\mathrm{CO}_{2}$ emissions are to be specified as primarily driven by fossil energy use, the latter being promoted by efforts of improving living conditions (increasing access to electricity, production activities, urbanisation, ...)

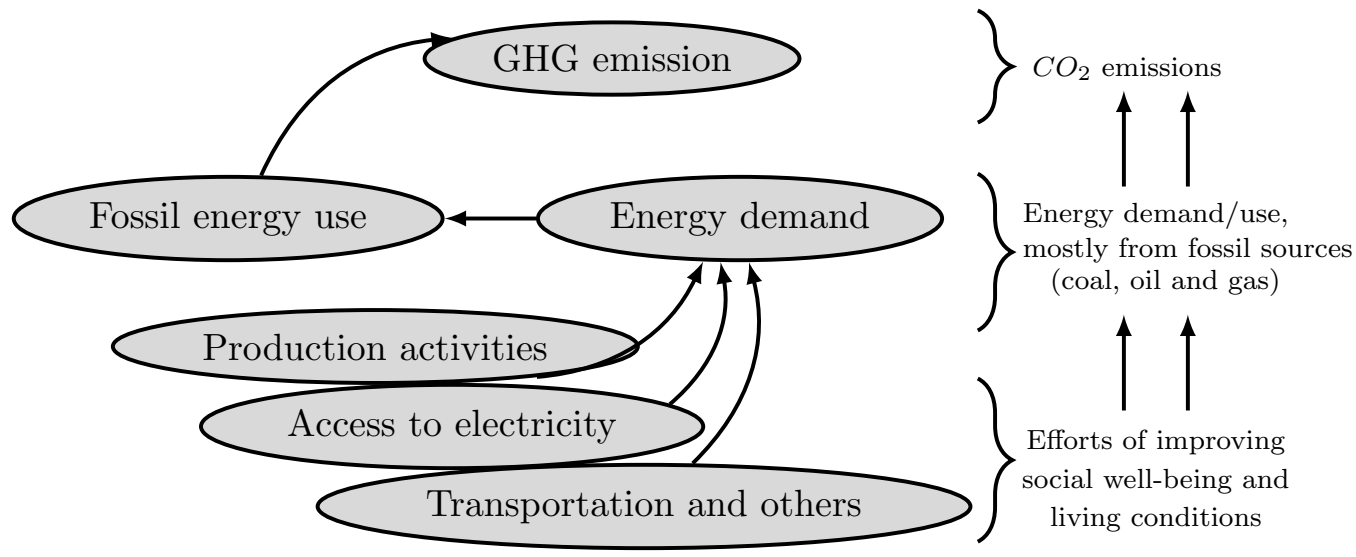

Figure 1. Synopsis of the GHG emissions, energy and human development nexus

Secondly, quality of life being at the heart of any development process, qualitative indicators of development should further be considered in investigating the relationship between GHG emissions, energy and development, especially in developing countries. For example, in SSA countries such as Equatorial Guinea, Gabon and Botswana, relatively high income levels are observed concurrently with very low levels of education and poor living conditions. ${ }^{1}$ This observation can be extended

\footnotetext{
${ }^{1}$ Regarding GDP p.c., Eq. Guinea, Gabon and Botswana are respectively $60^{t h}, 72^{\text {nd }}$ and $77^{\text {th }}$ in a total of 185 countries, 2017. They occupy the $144^{t h}, 115^{t h}$ and the $94^{t h}$ rank in HDI (Worldometers and UNDP (2019)).
} 
to other SSA countries to reveal the inappropriateness of using economic growth as indicator of human development in SSA. Qualitative indicators, including not only per capita GDP but also social dimensions such as life expectancy and education, seem more accurate proxies for living conditions (UNDP, 2019). Surprisingly, in existing literature, whether the research questions are the long-run dynamics, direction of causality (Huang et al., 2008; Joyeux and Ripple, 2011) or the drivers of GHG emissions and existence of an environmental Kuznets curve (Nguyen-Van, 2010; Azomahou et al., 2016), rare are the studies using qualitative measures of development, even so in the African context. This paper, in addition to a recursive modelling, intends to exploit Human Development Index (HDI) as indicator of development level. ${ }^{2}$

Finally, primary energies being directly harvested from natural resources, neighbouring Sub-Saharan African (SSA) countries sharing similar geographical characteristics, likely share comparable endowments in energy resources as well as correlated intensities in fossil energy use. Therefore, geographical characteristics or spillovers should be considered, when addressing primary energy use. Unfortunately, assessing the link between $\mathrm{CO}_{2}$ emissions, energy and human development in Africa, the two existing studies (Ouedraogo, 2013; Aglina et al., 2016) disregard geographical spillovers in both primary energy use and $\mathrm{CO}_{2}$ emissions. This study also intends to consider geographical spillovers in both primary energy use and $\mathrm{CO}_{2}$ emissions.

This paper contributes to the empirical literature on GHG emissions, energy and human development in SSA in two ways. Primarily, contrary to Omri (2013); Nguyen et al. (2019) and Soukiazis et al. (2019) who advocate for simultaneity, this study relies on theoretical arguments to claim a recursive mechanism. It shows that efforts of improving human well-being and economic development are not to blame for $\mathrm{CO}_{2}$ emissions. Furthermore, this study provides evidence of geographical spillovers in both fossil energy use and $\mathrm{CO}_{2}$ emissions across SSA. Our sample selection follows a simple rationale. On the one hand, very few studies can be identified addressing GHG emissions, energy and human development for the entire SSA. Studies doing so have very limited samples. On the other hand, given their colonial history (mostly former colonies), their common socio-economic characteristics (countries at early stages of development) and most crucially their geographical characteristics (contiguity), SSA appears to be the ideal sample this recursive spatial analysis can be applied to.

The remainder of the paper is organised as follows. The next Section reviews the related literature. Sections 3 and 4 present the data and describe our econometric specification. Section 5 presents and discusses the results of our empirical analysis. In Section 6, we check our results for robustness and draw some conclusions in Section 7.

\section{Related literature}

Following the founding works by Grossman and Krueger (1991, 1995) and Shafik and Bandyopadhyay (1992), a large literature has assessed the relationship between $\mathrm{CO}_{2}$ emissions, energy and income. This literature highlights the causal link between these variables and globally suggests that economic growth and energy use cause

\footnotetext{
${ }^{2}$ The UNDP (2019) defines HDI as a measure of average achievement in key dimensions of human development. Also, it considers that HDI 'should be the ultimate criteria for assessing the development of a country, not economic growth alone.'
} 
environmental pollution (Halicioglu, 2009; Gassebner et al., 2010; Liddle, 2013). This paper addressing the link between GHG emissions, primary energy use and human well-being, we wish to narrow down this literature review to studies using qualitative measures of human development instead of GDP per capita. ${ }^{3}$ Systematic and recent literature reviews of studies focusing on economic growth are presented by Ozturk (2010), Tiba and Omri (2017) and Mardani et al. (2019).

Besides economic growth, recent empirical studies have been questioning the role of qualitative measures of well-being (HDI, literacy rate and consumption) in energy consumption and GHG emissions. Although relatively short, this literature initiated, among others, by Pasternak (2000), Martinez and Ebenhack (2008) and $\mathrm{Wu}$ et al. (2010) enlightens the interactions between these phenomena. Pasternak (2000) and Martinez and Ebenhack (2008) analyses correlation between human development and energy use in most populated countries to conclude that large gains in human development are possible through access to energy in poor nations, as there is a significant association between electricity use and indicators of human development. Wu et al. (2010) note similarities in energy use and HDI inequalities across 129 countries from 1998 to 2007. Following these leading studies, Pîrlogea (2012) and Niu et al. (2013) use regression analysis to provide evidence on the role of energy and access to electricity in human well-being. Their results indicate that the higher the GDP per capita, the greater electricity consumption and the higher human development. Similarly, Roy et al. (2015) find results supporting a long-run relationship between energy and HDI which further suggest that energy use enhance social well-being. A takeaway appears in these studies. Similar to the income-energy nexus, a bidirectional causality (feedback hypothesis) appears between energy use and human well-being.

Given recent awareness on climate issues and increasing renewable energy use, a further aspect of the literature addressed how renewable energy use impacts social well-being. Overall, no convincing conclusion appears regarding the role of renewable energies in improving human development. On this, while Kazar and Kazar (2014) and Satrovic (2018) support the existence of a bidirectional causality between renewable energy and HDI, at least in the short-run, Wang et al. (2018) find no conclusive results. It can be observed that this specific area of environmental economics discussing human development and renewable energy consumption needs to be further explored. Regarding pollutant emissions and their link to energy and human development, inconclusive results are also noticeable. The existing studies on the latter topic also provide evidence indicating that energy use promotes human development, but remain inconclusive on how GHG emissions impact human wellbeing (Nguyen et al., 2019; Soukiazis et al., 2019; Rahman, 2020). On the same topic, Bedir and Yilmaz (2016) show that GHG emissions affect HDI only in four European countries (Iceland, Norway, Portugal, and Switzerland). In conclusion, contrary to energy use, which is shown to have a bidirectional causality with human development, the impact of GHG emissions on human well-being remains an open question.

In the case of countries at early stages of development, specifically SSA, even scarcer are studies considering qualitative measures of well-being when addressing

${ }^{3}$ This because the HDI appears to be a better indicator of human development and should be the ultimate criteria for assessing development (UNDP, 2019). 
the pollutant emissions, energy use and development nexus. Consequently, only the studies by Ouedraogo (2013) and Aglina et al. (2016) were found. Considering human well-being indicators such as life expectancy and literacy rate, among others, Aglina et al. (2016) find positive impacts of energy consumption on human well-being. Similar results appear in the study by Ouedraogo (2013), who assesses the co-movement and the causality between energy use, electricity consumption and HDI in the Economic Community of West African States. The results specifically show a positive cointegration relationship between electricity consumption and HDI, implying that electricity consumption enhances human development.

Conclusively, though the renewable energy use and economic growth debate remains controversial, the literature shows that energy consumption and access to electricity drive human development. It is first to note that the specifications, even when exploiting simultaneous equations system, are less theory derived, leading to regressions models directly linking income to GHG emissions. Secondly, no specific attention has been given to fossil energy use in low-income countries, modelling the latter as a direct driver of pollutant emissions rather than production activities. Finally, questions regarding geographical spillovers in primary energy consumption and GHG emissions have been largely disregarded, notwithstanding their importance for energy policy. The recursive mechanism proposed by this paper to address the $\mathrm{CO}_{2}$ emissionsenergy-human development nexus aims to fill these gaps.

\section{Model specification}

\subsection{Theoretical background}

Theoretical models on energy and resources use show that economic activities rely not only on labour and capital but also on energy resources to indirectly cause environmental degradation. Thereby, Stern and Cleveland (2004) and Arbex and Perobelli (2010) for instance consider a production technology using labour $(L)$, capital $(K)$ and energy $(E): Y=A L^{\alpha_{1}} K^{\alpha_{2}} E^{\alpha_{3}}$. It is to observe that the latter formulation links production activities (income level) to energy consumption. Moreover, the existing literature suggests a bidirectional causality between energy use and income (Niu et al., 2013; Roy et al., 2015), implying that not only economic growth depends on energy, still, also energy consumption conversely depends on income level. Exploiting these observations but also the resources harvest function of Eliasson and Turnovsky (2004) as well as the semi-logarithmic energy-development function by Steinberger and Roberts (2010), energy use per capita (in log) can be directly expressed as depending on income per capita among other socio-economic characteristics: $\log E U_{p c}=a_{0}+a_{1} \log Y_{p c} .{ }^{4}$ This equation constitutes the theoretical foundation for our regression model 2 linking energy use to human development.

Concerning GHG emissions, Conti et al. (2016) argue that 'because anthropogenic emissions of carbon dioxide result primarily from the combustion of fossil fuels, energy consumption is at the centre of the climate change debate'. Furthermore 'fossil-fuel systems, in particular, are the dominant contributors to the emissions

\footnotetext{
${ }^{4}$ Specifically, the resource harvest function states that harvesting mineral resource requires economic resources and efforts in terms of labour. The semi-logarithmic energy-development function (Pasternak, 2000; Steinberger and Roberts, 2010) states: $H D I=a+b \log E U$
} 
of these gases' (Dones et al., 2004). These arguments, in addition to theoretical models on the dirty energy-pollution nexus (Van der Ploeg and Withagen, 2012; Dato, 2017) directly link fossil energy use to environmental pollution. Therefore, we specify $\mathrm{CO}_{2}$ emissions (in log) as primarily depending on fossil energy use: $\log C O 2_{p c}=b_{0}+b_{1} \log E U_{p c}$. The latter formulation supports the regression model 1.

These theoretical discussions over equations 1 and 2 describe a recursive mechanism linking development level to energy use and afterwards fossil energy use to pollution, supporting our empirical strategy. Moreover, they question existing causality analyses directly linking GHG emissions to economic growth. Finally, they imply two obvious propositions: (i.) Efforts of improving living conditions (human development) strengthen primary energy use in SSA and (ii.) the higher primary energy use, the larger $\mathrm{CO}_{2}$ emissions. In addition, given the geographical contiguity of (most) SSA countries, the existence of spatial spillovers in energy and $\mathrm{CO}_{2}$ emissions across SSA is also postulated. These rationales will guide the recursive analysis on the relationship between GHG emissions, fossil energy consumption and human development.

\subsection{Econometric model}

Following with the discussions above, we define the regression models for $\mathrm{CO}_{2}$ emissions and energy as follows:

$$
\begin{array}{r}
\log C O 2_{i t}=b_{1} \log E U_{i t}+x_{1, i t} \beta+\varepsilon_{i t}+\epsilon_{i}, \quad \text { with } \varepsilon_{i t} \mid x_{1, i t}, E U_{i t} \sim i i d\left(0, \sigma_{\varepsilon}^{2}\right) \\
\log E U_{i t}=a_{1} H D I_{i t}+x_{2, i t} \alpha+v_{i t}+\nu_{i}, \quad \text { with } v_{i t} \mid x_{2, i t}, E U_{i t} \sim i i d\left(0, \sigma_{v}^{2}\right)
\end{array}
$$

where the index $i$ refers to country and $t$ to the year. $\varepsilon_{i t}$ and $v_{i t}$ stand for the error terms and $\epsilon_{i}$ and $\nu_{i}$ for individual effects. $\log C O 2_{i t}$ and $\log E U_{i t}$ respectively represent $\mathrm{CO}_{2}$ emissions and primary energy use per capita, while the matrices $x_{1}$ and $x_{2}$ stand for additional determinants (control variables) that will be considered.

Regarding control variables, $x_{1}$ and $x_{2}$, the recent literature mentions as drivers of $\mathrm{CO}_{2}$ emissions, population dynamics, urbanization, industrial production (Martínez-Zarzoso and Maruotti, 2011), openness to trade and political institution (Halicioglu, 2009; You et al., 2015). In addition, Aldy (2007) and Liddle (2013) mentioned GDP, while Soukiazis et al. (2019) consider education, spending on R\&D and development level as driving energy use. Data on most of these variables are available and will be introduced into the regression models.

Primary energies being harvested from natural resources, we intend to address geographical spillovers in energy use, as well as in resulting $\mathrm{CO}_{2}$ emissions. Indeed, 'everything is related to everything else, but near things are more related than distant things' (Tobler, 1970). Neighbouring SSA countries sharing similar geographical characteristics, likely have comparable endowments in energy resources and could also show correlated intensities in primary energy use and GHG emissions. Let $\omega_{n \times n}$ be a common-border based connectivity matrix, the spatial lag of $\mathrm{CO}_{2}$ emissions and energy use $\left(\sum_{j=1}^{n} w_{i j} C O 2_{j t}\right.$ and $\left.\sum_{j=1}^{n} w_{i j} E U_{j t}\right)$ will be introduced into the respective models. 


\subsection{Addressing endogeneity}

The feedback hypothesis in the energy and development relationship suggests that not only energy use depends on living condition (as in Eq. 2), but also that access to electricity or energy use reversely drives well-being. Arbex and Perobelli (2010) and Omri (2013) provide some theoretical and empirical discussions on this issue of reverse causality (endogeneity). Additionally, equations 1 and 2 in our case may suffer from omitted variables and measurement errors also leading to endogeneity, which will bias the estimated parameters if not properly addressed.

Addressing endogeneity, we rely on instrumental variables technique, using as instrument for HDI the one year lag of income per capita $\left(G D P_{p c, t-1}\right)$ and of life expectancy $\left(L E_{t-1}\right)$. These variables are highly correlated with HDI and are unlikely to directly drive energy consumption observed in period $t$. Therefore, they seem good instruments for human development. The regression model becomes the following, where the same included instruments are considered:

$$
\begin{gathered}
\log C O 2_{i t}=\rho_{c} \sum_{j=1}^{n} w_{i j} C O 2_{j t}+b_{1} \log E U_{i t}+x_{i t} \beta+\varepsilon_{i t}+\epsilon_{i}, \quad \varepsilon_{i t} \mid x_{i t} \sim i i d\left(0, \sigma_{\varepsilon}^{2}\right) \\
\log E U_{i t}=\rho_{e} \sum_{j=1}^{n} w_{i j} E U_{j t}+a_{1} H D I_{i t}+x_{i t} \alpha+v_{i t}+\nu_{i}, \quad v_{i t} \mid x_{i t} \sim i i d\left(0, \sigma_{v}^{2}\right) \\
H D I_{i t}=\varphi_{1} G D P_{p c, i, t-1}+\varphi_{2} L E_{i, t-1}+x_{i t} \delta+u_{i t}+\mu_{i}, \quad u_{i t} \mid x_{i t}, G D P, L E \sim i i d\left(0, \sigma_{\mu}^{2}\right)
\end{gathered}
$$

where $\rho_{c}$ and $\rho_{e}$ respectively traduce the geographical spillovers in $\mathrm{CO}_{2}$ emissions and primary energy use, while $\sum_{j=1}^{n} w_{i j} C O 2_{j t}$ and $\sum_{j=1}^{n} w_{i j} E U_{j t}$ represent for a country $i$ the average $\mathrm{CO}_{2}$ emissions and primary energy use in the neighbouring countries.

\section{Data and descriptive statistics}

Investigating the relationship between $\mathrm{CO}_{2}$ emissions, fossil energy use and human development, common determinants of GHG emissions and energy use identified in existing studies need to be considered. Thus, we collected data, among others, on primary energy use, $\mathrm{CO}_{2}$ emissions, HDI, GDP per capita, population dynamics, access to electricity and trade. The final dataset is constituted by 41 SSA countries and is reduced to the period between 1990 and 2013 due to missing values.

- Carbon dioxide emissions are used as indicator of GHG emissions in SSA. By definition, it includes carbon dioxide produced during consumption of solid, liquid, and gas fuels and gas flaring WDI (2019).

- Fossil Energy use: We consider as proxy for fossil energy use data on total primary energy consumption. Primary energy use refers to the direct use, or supply to users without transformation of energies directly harvested from natural resources and which are dominated by fossil energies (coal, oil and gas) (United Nations, 1997).

- Human development: Living conditions or human well-being at country-level is represented by the HDI, which is 'a summary measure of average achievement in key dimensions of human development: a long and healthy life, being knowledgeable and 
have a decent standard of living' (United Nations Development Programme, UNDP). Contrary to income per capita, the UNDP argues that HDI should be the ultimate criteria for assessing the development of a country. The HDI takes values ranging from 0 to 1 and is a more qualitative measure of living standard.

Table 1. Descriptive statistics

\begin{tabular}{|c|c|c|c|c|c|c|c|}
\hline & Units & $\mathrm{N}$ & Mean & St. Dev. & Min & Max & Source \\
\hline $\log . \mathrm{CO}_{2}$ emissions & M. tons per cap. & 984 & 5.469 & 1.333 & 2.373 & 9.197 & WDI \\
\hline log.Primary Energy use & $\mathrm{Kj}$. per capita & 984 & 15.306 & 1.182 & 12.616 & 18.622 & EIA \\
\hline log.GDP per capita & $\$$, PPP. 2011 & 984 & 7.597 & 0.899 & 5.508 & 10.833 & WDI \\
\hline HDI & index & 984 & 0.427 & 0.099 & 0.200 & 0.690 & UNDP \\
\hline log.Consumption expenditures & $\$$, PPP. 2011 & 696 & 6.504 & 0.815 & 5.151 & 8.443 & WDI \\
\hline Agricultural activities & in $\%$ of GDP & 984 & 28.659 & 16.787 & 0.892 & 78.655 & WDI \\
\hline Industrial activities & in $\%$ of GDP & 984 & 27.528 & 15.903 & 3.329 & 84.283 & WDI \\
\hline Natural resources rents & in $\%$ of GDP & 984 & 15.311 & 14.562 & 0.374 & 89.002 & WDI \\
\hline FDI, net inflows & in $\%$ of GDP & 984 & 4.226 & 10.651 & -82.892 & 161.824 & WDI \\
\hline Imports & in $\%$ of GDP & 984 & 43.803 & 36.326 & 7.066 & 424.817 & WDI \\
\hline Exports & in $\%$ of GDP & 984 & 30.468 & 19.788 & 3.335 & 124.393 & WDI \\
\hline Population growth & in $\%$ & 984 & 2.619 & 1.037 & -6.343 & 7.989 & WDI \\
\hline Urban population growth & in $\%$ & 984 & 4.066 & 1.729 & -7.103 & 17.598 & WDI \\
\hline Temperatures & ${ }^{\circ} \mathrm{C}$ & 943 & 24.646 & 3.280 & 12.628 & 29.541 & CCKP \\
\hline Total Rainfalls & in $\mathrm{mm}$ & 943 & $1,044.569$ & 596.912 & 70.418 & $3,282.239$ & CCKP \\
\hline Political stability & index & 984 & -0.680 & 0.897 & -2.989 & 1.183 & WDI \\
\hline Unrest (Riots and protests) & Counts & 656 & 15.848 & 50.408 & 0.000 & 993.000 & ACLED \\
\hline Poverty gap at $1.9 \$$ a day & \%, PPP. 2011 & 622 & 19.944 & 12.030 & 1.800 & 63.600 & WDI \\
\hline Access to electricity & in $\%$ & 982 & 51.450 & 25.489 & 0.010 & 100.000 & WDI \\
\hline Mean years of Education & years & 946 & 3.913 & 1.921 & 0.700 & 10.100 & UNDP \\
\hline Life expectancy & years & 984 & 53.146 & 5.946 & 27.610 & 65.914 & UNDP \\
\hline
\end{tabular}

Notes: $n=41$ SSA countries observed over 1990-2013, 24 periods. N varies because of missing values. ACLED stands for Armed Conflict Location \& Event Data and CCKP for "Climate Change Knowledge Portal".

- Control variables: Our dataset also includes data on industry and agriculture in share of GDP, population growth, access to electricity, openness to trade (imports and exports), net inflows foreign direct investments (FDI), as well as indicators of institutional characteristics, social unrest and weather differentials, among others.

Table 1 reports descriptive statistics of the variables involved in our study. By comparing the minimum values to the maximum for HDI, primary energy use and $\mathrm{CO}_{2}$ emissions, differences are observable, suggesting a relatively heterogeneous sample. Since these descriptive statistics do not provide any understanding of the geographical distribution of energy use and pollutant emissions in SSA allowing between countries comparisons, Figures 2 and 3 are proposed. Observing both maps, in addition to differences between countries, some similarities in the geographical distribution of energy use and $\mathrm{CO}_{2}$ emissions are quite striking. 


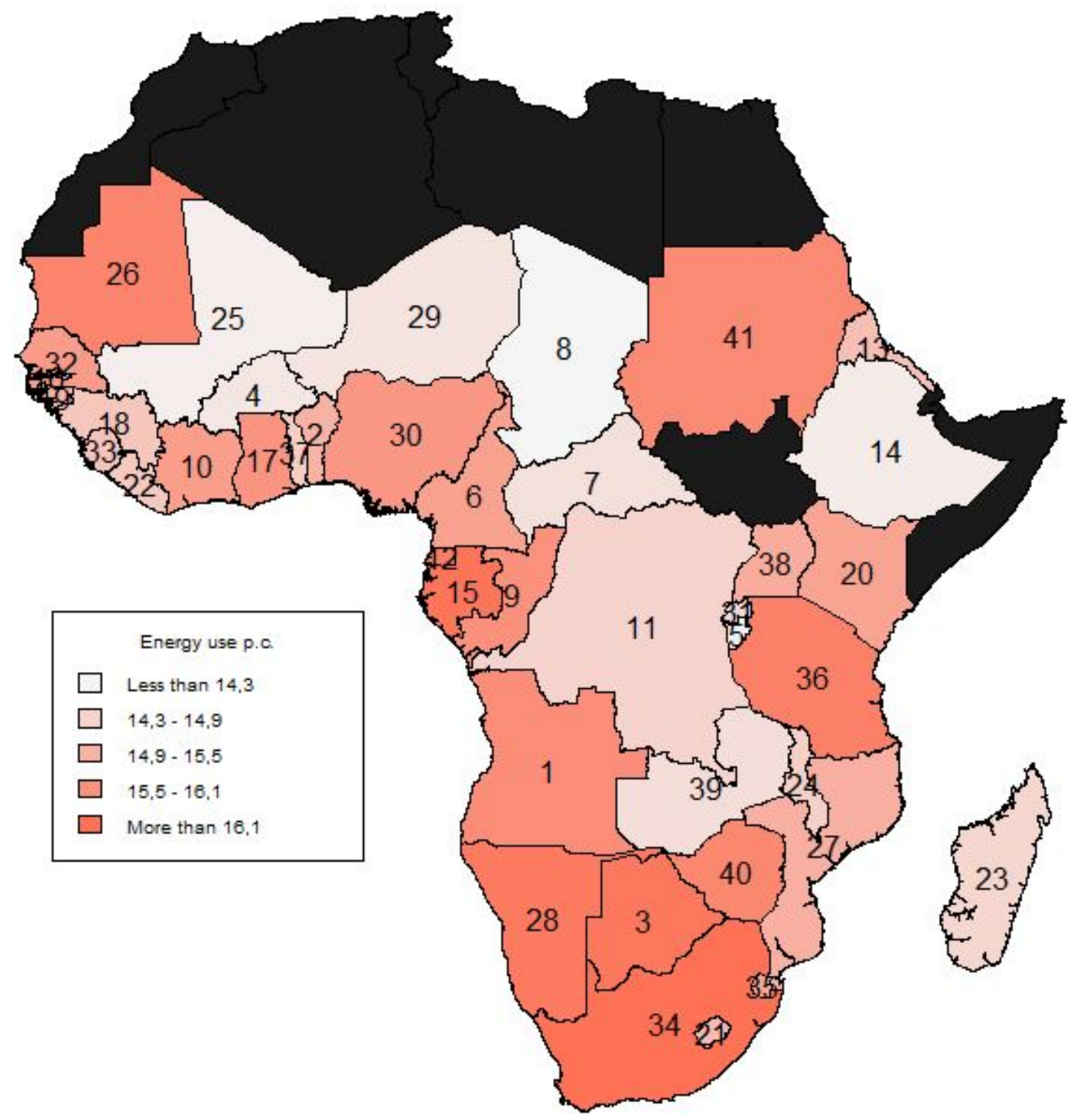

Figure 2. Mean primary energy use in SSA, 1990-2013

List of countries: 1 Angola, 2 Benin, 3 Botswana, 4 Burkina Faso, 5 Burundi, 6 Cameroon, 7 Central African Republic, 8 Chad, 9 Congo,Rep., 10 Cote d'Ivoire, 11 Congo, Dem. Rep., 12 Equatorial Guinea, 13 Eritrea, 14 Ethiopia, 15 Gabon, 16 Gambia, The, 17 Ghana, 18 Guinea, 19 Guinea Bissau, 20 Kenya, 21 Lesotho, 22 Liberia, 23 Madagascar, 24 Malawi, 25 Mali, 26 Mauritania, 27 Mozambique, 28 Namibia, 29 Niger, 30 Nigeria, 31 Rwanda, 312 Senegal, 33 Sierra Leone, 34 South Africa, 35 Swaziland, 36 Tanzania, 37 Togo, 38 Uganda, 39 Zambia, 40 Zimbabwe, 41 Sudan. 


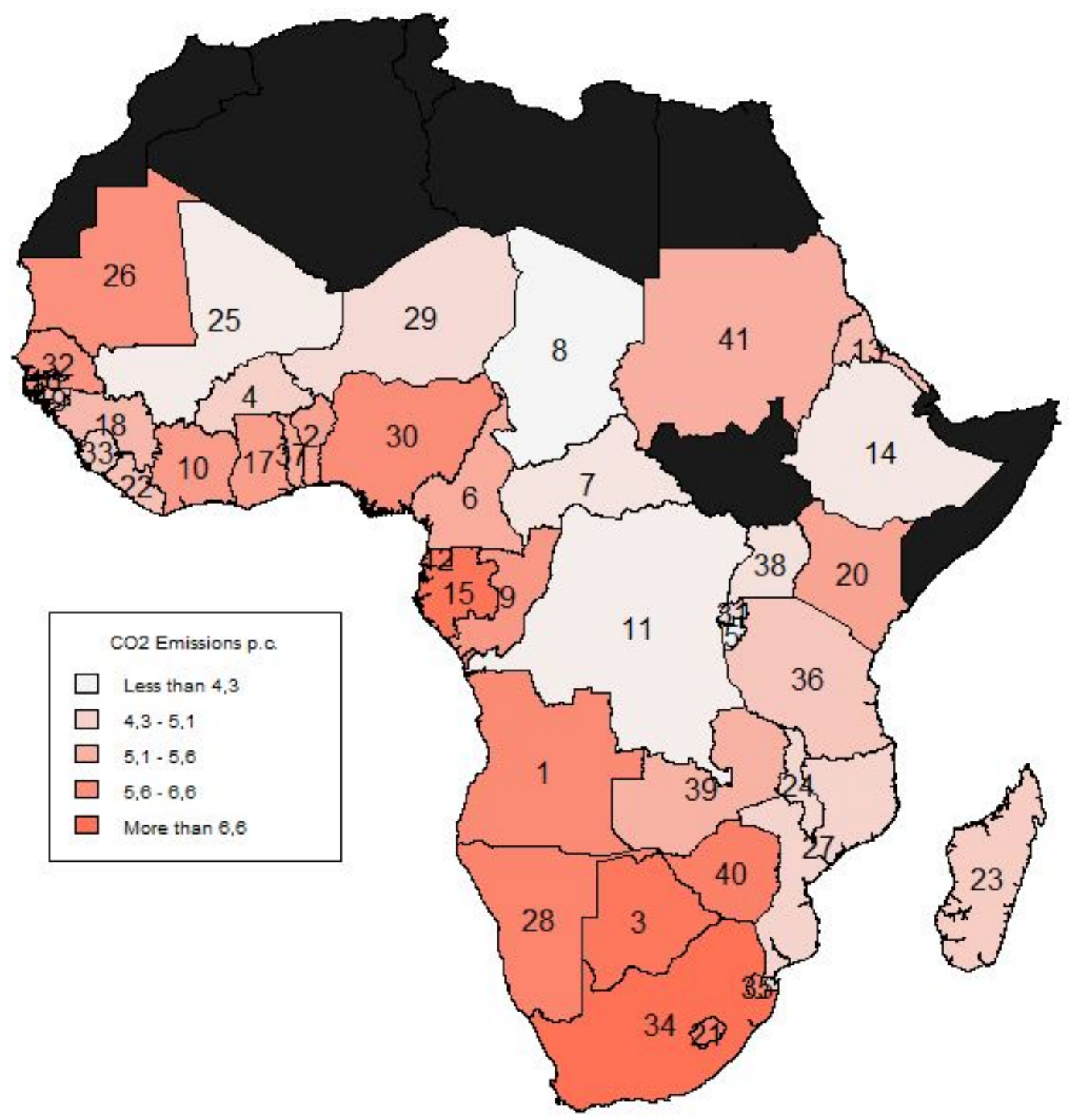

Figure 3. Mean $\mathrm{CO}_{2}$ emissions in SSA, 1990-2013

List of countries: 1 Angola, 2 Benin, 3 Botswana, 4 Burkina Faso, 5 Burundi, 6 Cameroon, 7 Central African Republic, 8 Chad, 9 Congo,Rep., 10 Cote d'Ivoire, 11 Congo, Dem. Rep., 12 Equatorial Guinea, 13 Eritrea, 14 Ethiopia, 15 Gabon, 16 Gambia, The, 17 Ghana, 18 Guinea, 19 Guinea Bissau, 20 Kenya, 21 Lesotho, 22 Liberia, 23 Madagascar, 24 Malawi, 25 Mali, 26 Mauritania, 27 Mozambique, 28 Namibia, 29 Niger, 30 Nigeria, 31 Rwanda, 312 Senegal, 33 Sierra Leone, 34 South Africa, 35 Swaziland, 36 Tanzania, 37 Togo, 38 Uganda, 39 Zambia, 40 Zimbabwe, 41 Sudan.

Initially, compared to inland countries, coastal located SSA countries mostly and concurrently show higher HDI, energy use and pollutant emissions (see Figure 2, 3 and A.1 in Supplementary Materials for HDI). Analysing the $\mathrm{CO}_{2}$-energy-HDI nexus in SSA, geographical characteristics such as regional spillovers should be addressed. Moreover, countries showing high level of primary energy use also appear to be characterized by high levels of $\mathrm{CO}_{2}$ emissions. However, an appropriate regression analysis will be more informative in answering the question whether or not efforts of improving living conditions (HDI) drive primary energy use and indirectly $\mathrm{CO}_{2}$ emissions. $^{5}$

\footnotetext{
${ }^{5}$ The data used in this paper are available in csv-file to those who wish to replicate our results
} 


\section{Estimation results}

\subsection{Are there geographical spillovers in primary energy use and $\mathrm{CO}_{2}$ emissions?}

Evidences of geographical spillovers in primary energy use and in $\mathrm{CO}_{2}$ emissions across SSA are a prerequisite for estimating the parameters of equations 3 and 4 . Therefore, we primarily test for the presence of spatial spillovers in each yearly wave of our panel dataset. Our argument being that countries sharing similar geographical characteristics (contiguous countries), likely have comparable endowments in energy resources and also correlated intensities in primary energy use and $\mathrm{CO}_{2}$ emissions, we exploit the connectivity matrix $\omega_{n \times n}$ (see Table A.3 in Supplementary Materials). ${ }^{6}$

Table 2. Test for spatial dependence in primary energy use and $\mathrm{CO}_{2}$ emissions

\begin{tabular}{ccc|cc}
\hline \hline & \multicolumn{2}{c}{ Primary energy use } & \multicolumn{2}{c}{$C O_{2}$ emissions } \\
\cline { 2 - 3 } \cline { 5 - 5 } Yearly waves of the panel dataset & Moran I & $p$-value & Moran I & $p$-value \\
\hline Wave 1990 & .133 & .076 & .223 & .012 \\
Wave 1991 & .116 & .099 & .409 & .000 \\
Wave 1992 & .093 & .141 & .426 & .000 \\
Wave 1993 & .089 & .149 & .387 & .000 \\
Wave 1994 & .083 & .163 & .378 & .000 \\
Wave 1995 & .088 & .151 & .415 & .000 \\
Wave 1996 & .067 & .202 & .382 & .000 \\
Wave 1997 & .072 & .188 & .465 & .000 \\
Wave 1998 & .100 & .128 & .468 & .000 \\
Wave 1999 & .130 & .080 & .485 & .000 \\
Wave 2000 & .168 & .039 & .474 & .000 \\
Wave 2001 & .187 & .027 & .484 & .000 \\
Wave 2002 & .242 & .007 & .466 & .000 \\
Wave 2003 & .241 & .008 & .492 & .000 \\
Wave 2004 & .224 & .011 & .464 & .000 \\
Wave 2005 & .279 & .003 & .457 & .000 \\
Wave 2006 & .276 & .003 & .455 & .000 \\
Wave 2007 & .304 & .002 & .462 & .000 \\
Wave 2008 & .329 & .000 & .471 & .000 \\
Wave 2009 & .326 & .001 & .472 & .000 \\
Wave 2010 & .344 & .000 & .466 & .000 \\
Wave 2011 & .321 & .000 & .456 & .000 \\
Wave 2012 & .318 & .001 & .456 & .000 \\
Wave 2013 & .312 & .001 & .455 & .000 \\
\hline \hline
\end{tabular}

Notes: Moran-I test under randomisation using data on primary energy use and $\mathrm{CO}_{2}$ emissions per capita (in $\log ) . H_{0}$ is no spatial dependence. Each yearly wave consists of 41 observations.

The test results (Table 2) in $71 \%$ of the case show statistically significant spatial spillovers in primary energy use among SSA countries. This indicates that modelling primary energy use, spatial autocorrelation should be considered as done in equation 4 . $\mathrm{CO}_{2}$ emissions being direct consequences of fossil energy use, spatial autocorrelations are also expected in data on $\mathrm{CO}_{2}$ emissions. The test results in $100 \%$ of the case support the latter perspective by also indicating statistically significant spatial effects. Finally, we perform the Durbin-Wu-Hausman test, the results of which largely support a fixed-effects specification. (see Table A.1 in Supplementary Materials). ${ }^{7}$

\footnotetext{
${ }^{6}$ The matrix $\omega_{n \times n}$ is based on contiguity principle. See Table A.3 in Supplementary Materials for details.

${ }^{7}$ The Hausman test compares fixed-effects to random-effects specification for panel data models.
} 


\subsection{On living conditions or human development in SSA}

Our specification introduces the model for human development (Eq. 5) as a first-stage regression, addressing endogeneity issues. Nevertheless, its outcomes remain crucial for the pollution-energy-development analysis intended in the paper. Table 3 reports the results of estimating fixed-effects models for HDI, exploiting the one year lag of GDP per capita $\left(G D P_{p c, t-1}\right)$ and life expectancy $\left(L E_{t-1}\right)$ as excluded instrumental variables. ${ }^{8}$ Subsequently, the predicted values of HDI will be used in estimating the parameters of the model for primary energy use in SSA (Eq. 4). The following discussions are essentially based on the model specification FE IV-ii, as the latter shows the highest predictive power (Adj. R-Squared).

Table 3. Standard FE regression model for Human Development Index

\begin{tabular}{|c|c|c|c|c|c|}
\hline \multirow[b]{2}{*}{ Covariates / Models } & \multicolumn{4}{|c|}{ First stage regression } & \multirow[b]{2}{*}{ FE IV-ii } \\
\hline & FE I & FE II & FE III & FE IV-i & \\
\hline Lag.lnGDP per capita & $.026^{* * *}(.005)$ & $.031^{* * *}(.006)$ & $.024^{* * *}(.007)$ & $.032^{* * *}(.006)$ & $.032^{* * *}(.006)$ \\
\hline Life expectancy & $.008^{* * *}(.002)$ & $.008^{* * *}(.000)$ & $.008^{* * *}(.000)$ & $.007^{* * *}(.002)$ & $.007^{* * *}(.003)$ \\
\hline Agriculture, GDP share & $-.010^{* * *}(.001)$ & $-.009^{* * *}(.001)$ & $-.007^{* * *}(.001)$ & $-.013(.013)$ & $-.013(.013)$ \\
\hline Industry, GDP share & $-.004^{* *}(.002)$ & $-.005^{* *}(.002)$ & $-.004^{* *}(.002)$ & $-.001(.001)$ & $-.001(.002)$ \\
\hline Rents of nat. resources & $.005^{* * *}(.001)$ & $.005^{* * *}(.001)$ & $.003^{* * *}(.001)$ & $.004(.011)$ & $.004(.011)$ \\
\hline FDI, net inflows & & $.007(.010)$ & $.008(.011)$ & $-.003^{* *}(.001)$ & $-.003^{* *}(.001)$ \\
\hline Imports, GDP share & & $.009^{*}(.005)$ & $.007(.006)$ & $.006(.004)$ & $.006(.005)$ \\
\hline Exports, GDP share & & $-.002(.010)$ & $-.004(.009)$ & $-.001(.001)$ & $-.001(.001)$ \\
\hline Population growth & & & $.003^{* *}(.001)$ & $.007^{* * *}(.002)$ & $.007^{* * *}(.002)$ \\
\hline Urban population growth & & & $-.002^{* * *}(.000)$ & $-.003(.002)$ & $-.003(.002)$ \\
\hline Average Temperatures & & & $.017^{* * *}(.002)$ & $.006(.017)$ & $.006(.018)$ \\
\hline Total rainfalls, yearly & & & $.013^{* * *}(.004)$ & $-.008(.043)$ & $-.008(.040)$ \\
\hline Political stability & & & & $-.004^{*}(.002)$ & $-.004^{*}(.002)$ \\
\hline Riots incidence & & & & $-.003(.002)$ & $-.003(.002)$ \\
\hline Poverty gap, at $1.9 \$$ & & & & $-.036^{* * *}(.009)$ & $-.036^{* * *}(.008)$ \\
\hline Access to electricity & & & & $.027^{* * *}(.010)$ & $.027^{* * *}(.010)$ \\
\hline Mean years of education & & & & $.015^{* * *}(.002)$ & $.015^{* * *}(.002)$ \\
\hline Intercept & & & & & $-.233^{* * *}(.057)$ \\
\hline \multicolumn{5}{|c|}{ Origin of the colonial power (categorical, ref. = not colonized): } & \\
\hline Belgian & & & & & $-.038^{* * *}(.013)$ \\
\hline British & & & & & $-.056^{* * *}(.011)$ \\
\hline French & & & & & $-.059^{* * *}(.016)$ \\
\hline Portuguese & & & & & $-.057^{* * *}(.008)$ \\
\hline Country dummy & & & & & $\checkmark$ \\
\hline Observations & 946 & 946 & 915 & 557 & 557 \\
\hline F-stat ( $p$-value) & $646.501(.000)$ & $409.631(.000)$ & $333.484(.000)$ & $228.727(.000)$ & $631.30(.000)$ \\
\hline Adj. R-Squared & .771 & .774 & .812 & .873 & .984 \\
\hline
\end{tabular}

Notes: Dependent variable is the Human Development Index. In bracket are bootstrapped standard errors. Lag.lnGDP per capita and Life expectancy are the excluded instrumental variables used in the first stage. ‘**,,${ }^{* *}$, and ${ }^{* *}$, respectively stand for significance level at 1,5 and $10 \%$.

Observing the results, both our instrumental variables are pertinent predictors of human development across SSA. As GDP per capita and life expectancy are

${ }^{8}$ Though the Hausman test suggests a random-effects specification for FE III (see Table A.1), we estimate a fixed-effects model, since the latter remains consistent. The results discussions are all based on FE IV-ii 
involved in computing the HDI, such results are predictable and principally support the statistical relevance of our instrumental variables.

Regarding control variables, mean years of education and access to electricity significantly enhance human development in Sub-Saharan Africa, confirming conclusions by Ouedraogo (2013) and Aglina et al. (2016). Contrary to access to electricity and education, FDI have a negative effect on human development in SSA. FDI in developing countries being very often attracted by resource endowments, oils deposits and even corruption (Melo et al., 2015), their primary goal seems not to be improving living conditions in SSA.

'The colonial origins of comparative development' literature (Acemoglu et al., 2001, 2012) sheds light on how colonisation shapes current institutions and human development in former colonies. Following the latter, we address historical characteristics of SSA by controlling for the origin of the colonial power as proposed by Lawson and Nguyen-Van (2020). The estimated parameters show that compared to not-colonized SSA countries, being a former colony undermines social well-being, independently of the colonial power's origin. Since colonisation has derailed countries from their natural path, former colonies of SSA hold institutions which derive from colonial and extractive institutions and consequently produce relatively poor performances in terms of education, income and standard of living. Thereby, it is to observe that the highest adverse impact for human development appears in former French colonies. Such a result indicates that the evidence regarding the colonial origin of comparative development can also be extended to human well-being. In contrast to the origin of the colonial powers categorical variable, improvement of living conditions (increase in HDI) in SSA can be expected to positively drive fossil energy use in SSA. The HDI-energy nexus is discussed in the next Section.

\subsection{On fossil energy use and human development in SSA}

Our regression model (Eq. 4) assumes that fossil energy use is promoted by efforts of improving living conditions and, hence, relates primary energy use to the index of human development. Exploiting predicted values of HDI from the first-stage regression (Eq. 5), we perform a second-stage regression for primary energy use per capita accounting for geographical spillovers. This delivers pertinent results regarding the causal link between living conditions and energy use (Table 4). The following discussions are based on model FE IV-ii.

Firstly, the estimated parameter for $\sum_{j=1}^{n} w_{i j} E U_{j t}$ supports the existence of positive geographical spillovers in primary energy use, as suggested by the Moran I-tests for spatial effects (Table 2). Based on the latter, one can argue that neighbouring SSA countries, sharing similar geographical characteristics, likely have comparable endowments in energy resources and actually show co-related intensities in primary energy use. In addition to geographical spillovers, HDI positively drives energy use implying that efforts of improving living conditions increase energy demand and consequently fossil energy use in SSA. A similar positive relationship between HDI and energy consumption has been explored in recent studies, among others, by Niu et al. (2013) and Arto et al. (2016). In contrast to Pîrlogea (2012), Niu et al. (2013) on the reverse hypothesis, Arto et al. (2016) argues that efforts of improving human well-being 
drive energy use in SSA. Finally, since African countries appear among the most dynamic economies, a collective increase in primary energy use is to expect across SSA.

Table 4. FE Spatial lag model Primary Energy Use

\begin{tabular}{|c|c|c|c|c|c|}
\hline \multirow[b]{2}{*}{ Covariates / Models } & \multicolumn{4}{|c|}{ Second stage regression } & \multirow[b]{2}{*}{ FE IV-ii } \\
\hline & FE I & FE II & FE III & FE IV-i & \\
\hline Spatial lag of energy use, $\rho_{e}$ & $.227^{* * *}(.040)$ & $.167^{* * *}(.037)$ & $.120^{* * *}(.039)$ & $.179^{* * *}(.051)$ & $.179^{* * *}(.052)$ \\
\hline Human Development index & $1.657^{* * *}(.220)$ & $1.555^{* * *}(.201)$ & $1.792^{* * *}(.208)$ & $.760^{* *}(.377)$ & $.760^{* *}(.375)$ \\
\hline Agriculture, GDP share & $.007^{* *}(.003)$ & $.005^{* *}(.002)$ & $.006^{* *}(.002)$ & $.003(.003)$ & $.003(.003)$ \\
\hline Industry, GDP share & $.016^{* * *}(.002)$ & $.011^{* * *}(.002)$ & $.011^{* * *}(.002)$ & $.012^{* * *}(.003)$ & $.012^{* * *}(.003)$ \\
\hline Rents of nat. resources & $-.014^{* * *}(.003)$ & $-.013^{* * *}(.002)$ & $-.015^{* * *}(.002)$ & $-.012^{* * *}(.003)$ & $-.012^{* * *}(.003)$ \\
\hline FDI, net inflows & & $-.004(.016)$ & $-.006(.017)$ & $-.004(.018)$ & $-.004(.018)$ \\
\hline Imports, GDP share & & $-.007^{* * *}(.001)$ & $-.006(.018)$ & $-.002^{*}(.001)$ & $-.002^{*}(.001)$ \\
\hline Exports, GDP share & & $.012(.002)$ & $.012^{* * *}(.002)$ & $.007^{* * *}(.002)$ & $.007^{* * *}(.002)$ \\
\hline Population growth & & & $-.040^{* * *}(.020)$ & $.018(.030)$ & $.018(.029)$ \\
\hline Urban population growth & & & $-.014(.015)$ & $.004(.022)$ & $.004(.021)$ \\
\hline Average Temperatures & & & $.020(.024)$ & $.045^{*}(.028)$ & $.045^{*}(.028)$ \\
\hline Total rainfalls, yearly & & & $-.006(.007)$ & $.003(.007)$ & $.003(.006)$ \\
\hline Political stability & & & & $-.009(.024)$ & $-.009(.023)$ \\
\hline Riots incidence & & & & $.003(.002)$ & $.003(.002)$ \\
\hline Poverty gap, at $1.9 \$$ & & & & $.004^{* *}(.002)$ & $.004^{* *}(.002)$ \\
\hline Access to electricity & & & & $.011^{* * *}(.002)$ & $.011^{* * *}(.002)$ \\
\hline Mean years of education & & & & $-.032(.031)$ & $-.032(.032)$ \\
\hline Intercept & & & & & $1.151^{* * *}(.095)$ \\
\hline $\begin{array}{l}\text { Origin of the colonial power } \\
\text { Belgian }\end{array}$ & categorical, ref. & $=$ not colonized): & & & $-1.981^{* * *}(.013)$ \\
\hline British & & & & & $-.872^{* * *}(.011)$ \\
\hline French & & & & & $-2.156^{* * *}(.016)$ \\
\hline Portuguese & & & & & $-.770^{* * *}(.008)$ \\
\hline Country dummy & & & & & $\checkmark$ \\
\hline Observations & 946 & 946 & 915 & 557 & 557 \\
\hline F-stat ( $p$-value) & $29.364(.000)$ & $54.868(.000)$ & $40.376(.000)$ & $11.416(.000)$ & $354.9(.000)$ \\
\hline Adj. R-Squared & .140 & .293 & .321 & .397 & .972 \\
\hline
\end{tabular}

Notes: Dependent variable is primary energy use per capita. In brackets are bootstrapped standard errors. (***), '**) and ${ }^{(*)}$ respectively stand for significance level at 1, 5 and $10 \%$.

Socio-economic variables reflecting the structure of economic production, openness to trade, demographic change, weather differentials and social unrest have been introduced into the regression model. Since electricity production in SSA mostly exploits oil, gas and coal sources (approximately $70 \%$ of the total, WDI (2019)), electricity supply and access to electricity are potential drivers of primary energy use in SSA. As expected, our empirical results show that access to electricity significantly promotes energy use, similar to industrial production and exports in GDP. These predictable outcomes suggest that increase in population share with access to electricity and economic production in the industry sector intensify energy demand which resolve into fossil energy consumption. Contrary to exports, the GDP share of imports negatively affects energy use and indicates that while SSA countries utilise fossil energies to produce and export goods (mostly raw materials and primary goods), imports of goods and services evidently do not participate in increasing energy demand. 
Conclusively, the estimated parameter for FDI shows no significant effect on energy use, disproving the pollution haven hypothesis regarding fossil energy use in SSA. ${ }^{9}$ Interestingly, the rents of natural resources show a negative and statistically significant link to primary energy use, i.e. the more SSA economies rely on resource rents, the less fossil energy they utilise. Analysing such an effect, we first observe that the share of resource rents in GDP (resource harvest) does not significantly enhance human well-being in accordance with the resource curse hypothesis. ${ }^{10}$ Whether or not the negative link between resource rents and energy use characterises the resource curse paradox is left to future research.

\subsection{On fossil energy use and $\mathrm{CO}_{2}$ emissions in SSA}

This paper argues that economic growth is not to blame for GHG emissions and identifies $\mathrm{CO}_{2}$ emissions as direct consequences of fossil energy consumption. Thus, our regression model 3 relates $\mathrm{CO}_{2}$ emissions to energy use (values predicted from Eq. 4), accounting for geographical spillovers, access to electricity, openness to trade and further socio-economic variables.

The estimated parameter for $\sum_{j=1}^{n} w_{i j} C O 2_{j t}$ is positive and statistically significant. This confirms the existence of spatial effects in $\mathrm{CO}_{2}$ emissions and implies that SSA countries do not only show co-related intensities of fossil energy consumption, which also reflects into increasing carbon dioxide emissions (see Table 5). Fossil energy use being at the heart of $\mathrm{CO}_{2}$ emissions, primary energy use and population access to electricity are both expected to significantly enhance $\mathrm{CO}_{2}$ emissions. The results clearly support such a perspective by showing a positive and significant impact of primary energy use on $\mathrm{CO}_{2}$ emissions. Similar conclusions advocating for causal effects running from energy to GHG emissions are also observed in the recent contributions by Omri (2013) and Soukiazis et al. (2019), among others. Globally, based on our results, the expected collective increase in primary energy use across SSA countries is also to associate with growing $\mathrm{CO}_{2}$ emissions and further environmental consequences.

Among control variables, very appealing results appear regarding the role of access to electricity, FDI and natural resources rents. Access to electricity driving energy demand and fossil energy use is positively linked to $\mathrm{CO}_{2}$ emissions. While natural resource rents are not significant for human development (and negatively affect primary energy use), they are positively related to $\mathrm{CO}_{2}$ emissions. It is to acknowledge that the latter outcome raises questions on the resource curse hypothesis, on the relationship between resource rents and energy as well as on the resource rents- $\mathrm{CO}_{2}$ emissions nexus. In fact, as there is a negative link between resource rents and energy, one expects a similar link between resource rents and $\mathrm{CO}_{2}$ emissions. ${ }^{11} \mathrm{~A}$ profound investigation on the forces behind this outcome is left for future research for not being the aim of this paper. Nevertheless, since non-linearities are possible justifications of such surprising outcomes, the general patterns of each of these nexuses are assessed. A U-shaped curve appears for each of the mentioned relationships, supporting the

\footnotetext{
${ }^{9}$ The pollution haven hypothesis states that environmental regulations will move polluting activities (of multinationals) for tradeable products to poorer countries (Eskeland and Harrison, 2003).

${ }^{10}$ The resource curse hypothesis refers to the paradox that economies abundant endowment in natural resources tend to show low-level of economic development (Ross, 2015).

${ }^{11}$ We thank an anonymous reviewer for drawing our attention to this specific relationship.
} 
non-linearity postulate (see Figures ??, A.2 and A.3). Hence, a feasible explanation of this unpredictable result is the utilisation of a linear specification for the control variables, also for resource rents. Finally, net inflows FDI show a negative impact on $\mathrm{CO}_{2}$ emissions, implying that investments made by foreigners into business interests in SSA countries do not systematically increase GHG emissions and environmental degradation. The latter result also disproves the pollution haven hypothesis concerning FDI.

Table 5. FE Spatial lag model of $\mathrm{CO}_{2}$ Emissions

\begin{tabular}{|c|c|c|c|c|c|}
\hline \multirow[b]{2}{*}{ Covariates / Models } & \multicolumn{4}{|c|}{ Third stage regression } & \multirow[b]{2}{*}{ FE IV-ii } \\
\hline & FE I & FE II & FE III & FE IV-i & \\
\hline Spatial lag of $\mathrm{CO}_{2}, \rho_{c}$ & $.149^{* * *}(.045)$ & $.146^{* * *}(.045)$ & $.195^{*}(.053)$ & $.213^{* * *}(.075)$ & $.213^{* * *}(.069)$ \\
\hline Primary Energy use & $.308^{* * *}(.042)$ & $.267^{* * *}(.038)$ & $.327^{* * *}(.001)$ & $.187^{* * *}(.027)$ & $.187^{* * *}(.026)$ \\
\hline Agriculture, GDP share & $.005^{* *}(.002)$ & $.005^{* *}(.002)$ & $.006^{* *}(.002)$ & $.006^{*}(.003)$ & $.006^{* *}(.002)$ \\
\hline Industry, GDP share & $.001(.003)$ & $-.003(.002)$ & $-.004^{*}(.002)$ & $-.001(.003)$ & $-.001(.003)$ \\
\hline Rents of nat. resources & $.006^{* * *}(.002)$ & $.005^{* *}(.002)$ & $.004^{*}(.002)$ & $.007^{* * *}(.002)$ & $.007^{* * *}(.002)$ \\
\hline FDI, net inflows & & $-.004(.015)$ & $-.007(.017)$ & $-.005^{* *}(.002)$ & $-.005^{* * *}(.001)$ \\
\hline Imports, GDP share & & $-.004^{* * *}(.001)$ & $-.003^{* * *}(.001)$ & $.001(.001)$ & $.001(.001)$ \\
\hline Exports, GDP share & & $.010^{* * *}(.002)$ & $.009^{* * *}(.002)$ & $-.002(.002)$ & $-.002(.002)$ \\
\hline Population growth & & & $-.006(.012)$ & $.046(.029)$ & $.046(.029)$ \\
\hline Urban population growth & & & $-.027^{* *}(.013)$ & $-.039^{*}(.024)$ & $-.039^{*}(.024)$ \\
\hline Average Temperatures & & & $.095^{* * *}(.025)$ & $.024(.027)$ & $.024(.027)$ \\
\hline Total rainfalls, yearly & & & $.011(.007)$ & $.012^{* *}(.005)$ & $.012^{* *}(.005)$ \\
\hline Political stability & & & & $.005(.024)$ & $.005(.024)$ \\
\hline Riots incidence & & & & $.001(.001)$ & $.001(.001)$ \\
\hline Poverty gap, at $1.9 \$$ & & & & $-.010^{* * *}(.002)$ & $-.010^{* * *}(.003)$ \\
\hline Access to electricity & & & & $.007^{* * *}(.001)$ & $.007^{* * *}(.002)$ \\
\hline Mean years of education & & & & $-.107^{* *}(.029)$ & $-.107^{* *}(.031)$ \\
\hline Intercept & & & & & $2.014^{* * *}(.737)$ \\
\hline \multirow{2}{*}{\multicolumn{5}{|c|}{ Origin of the colonial power (categorical, ref. = not colonized): }} & \\
\hline & & & & & $-1.762^{* * *}(.229)$ \\
\hline British & & & & & $-.289^{* *}(.121)$ \\
\hline French & & & & & $-.963^{* * *}(.267)$ \\
\hline Portuguese & & & & & $-.012(.178)$ \\
\hline Country dummy & & & & & $\checkmark$ \\
\hline Observations & 946 & 946 & 915 & 557 & 557 \\
\hline F-stat ( $p$-value) & $32.766(.000)$ & $33.851(.000)$ & $35.412(.000)$ & $11.949(.000)$ & $473.0(.000)$ \\
\hline Adj. R-Squared & .154 & .191 & .289 & .298 & .979 \\
\hline
\end{tabular}

Notes: Dependent variable is $\mathrm{CO}_{2}$ emissions per capita. Lag.lnGDP per capita and Life expectancy are the excluded instrumental variables used in the first stage. In bracket are bootstrapped standard errors. ' $* * *$, , ‘**, and ${ }^{*}$ ', respectively stand for significance level at 1,5 and $10 \%$.

Globally, it is to note that the recursive regression model introduced by this paper to assess the mechanism through which the relationship between human development, energy and $\mathrm{CO}_{2}$ emissions operates delivers results supporting our hypotheses. Firstly, these results show that efforts of improving human well-being are the direct forces driving fossil energy consumption in SSA. Secondly, $\mathrm{CO}_{2}$ emissions appear as by-products of primary energy use, implying that economic growth and efforts of improving living condition are not directly to blame for GHG emissions. Finally, our preliminary tests and regression analysis support the existence of geographical spillovers in both primary energy consumption and $\mathrm{CO}_{2}$ emissions. In the light of these results, a collective increase of primary energy use and pollutant emissions are to expect in a near future 
in individual SSA countries, where population growth, increasing access to electricity and economic performances are being observed.

\section{Robustness check and non-parametric perspectives}

\subsection{Robustness analysis}

This paper argues that causality analyses mostly failed to address the mechanisms through which the $\mathrm{CO}_{2}$ emissions, energy and development nexus operates, by ignoring its recursive nature, qualitative measures of well-being, as well as geographical spillovers. Moreover, by directly linking income to GHG emissions (e.g. causality analyses), existing studies hold economic growth responsible for GHG emissions, although a direct link between these phenomena remains debatable. Thus, we propose a recursive analysis of the relationship between $\mathrm{CO}_{2}$ emissions, primary energy use and human development for a sample of SSA countries. Our results mainly support the argument that efforts of improving human development create an energy demand and the higher fossil energy use, the higher GHG emissions. To test these conclusions for robustness, we proceed exactly as primarily, however, considering a different measure of human well-being, household final consumption expenditures.

\section{- Using an alternative measure of living conditions}

Using data on household expenditures on final consumption as indicator of living conditions shows slight changes in the estimated parameters, though, not in the signs and causal links previously established. ${ }^{12}$ Observing the results of the first stage regression or for household final consumption (Table 6), the model shows high predictive power in addition to being globally significant. The one year lag per capita GDP, agricultural production and educational level positively drive household final consumption. As previously established, colonial characteristics of SSA countries reveal that being a former colony negatively affects human development, supporting the literature on the role of history in comparative development (Acemoglu et al., 2001; Nunn, 2009).

Regarding energy use, the results support the existence of geographical spillovers in primary energy use and confirm the role played by efforts of improving living conditions (household final consumption) in enhancing fossil energy consumption. Moreover, common determinants of fossil energy use in SSA such as industrial production, exportations and access to electricity remain statistically significant. Net inflows FDI is insignificant for primary energy use, while the rents of natural resources show, as previously, a negative effect.

Finally, observing the results for $\mathrm{CO}_{2}$ emissions, the spatial spillovers in GHG emissions remains statistically significant. As previously shown, increasing energy demand, thus fossil energy use and access to electricity (which mainly results from coal sources) enhance GHG emissions in Africa. Among control variables, the level of education and FDI show a negative link, while natural resource rents surprisingly show

${ }^{12}$ The WDI (2019) defines the household final consumption expenditure (private consumption) as 'the market value of all goods and services, including durable products (such as cars, washing machines, and home computers), purchased by households'. 
as previously a positive link to $\mathrm{CO}_{2}$ emissions per capita. As discussed above (see Figures A.2 and A.3), there seems to be non-linearity in the resource rents-energy use and the resource rent-GHG emissions nexus which explains the conflicting results, when a linear specification is used. Since these specific relationships are not the focal point of this study, a profound assessment of that is left to future research.

Table 6. $\mathrm{CO}_{2}$ emission, primary energy use and household final consumption

\begin{tabular}{|c|c|c|c|}
\hline & \multicolumn{3}{|c|}{ Dependent variables: } \\
\hline & Household final consumption & Primary energy use & $\mathrm{CO}_{2}$ emissions \\
\hline Lag.lnGDP per capita & $.363^{* * *}(.064)$ & & \\
\hline Life expectancy & $.003(.003)$ & & \\
\hline Spatial lag of energy use & & $.154^{* *}(.073)$ & \\
\hline H. final consumption exp. p.c. & & $.204^{* * *}(.066)$ & \\
\hline Spatial lag of $\mathrm{CO}_{2}$ & & & $.396^{* * *}(.073)$ \\
\hline Primary Energy use & & & $.213^{* * *}(.034)$ \\
\hline Agriculture, GDP share & $.007^{* * *}(.002)$ & $.010^{* * *}(.004)$ & $.008^{* *}(.004)$ \\
\hline Industry, GDP share & $.001(.002)$ & $.018^{* * *}(.003)$ & $-.002(.003)$ \\
\hline Rents of nat. resources & $-.001(.001)$ & $-.013^{* * *}(.002)$ & $.009^{* * *}(.002)$ \\
\hline FDI, net inflows & $-.001(.001)$ & $.001(.002)$ & $-.004^{* *}(.002)$ \\
\hline Imports, GDP share & $-.002^{* * *}(.0005)$ & $-.002^{* *}(.001)$ & $.002^{* * *}(.001)$ \\
\hline Exports, GDP share & $.002(.001)$ & $.009^{* * *}(.002)$ & $-.004^{* *}(.002)$ \\
\hline Population growth & $.093^{* * *}(.024)$ & $.037(.041)$ & $.023(.037)$ \\
\hline Urban population growth & $-.062^{* * *}(.018)$ & $-.001(.031)$ & $-.022(.028)$ \\
\hline Average Temperatures & $.030(.024)$ & $.096^{* *}(.043)$ & $.029(.038)$ \\
\hline Total rainfalls, yearly & $-.00004(.0001)$ & $.0001(.0001)$ & $.0001(.0001)$ \\
\hline Political stability & $.034(.019)$ & $-.037(.034)$ & $-.060 *(.031)$ \\
\hline Riots incidence & $-.0003(.0003)$ & $.0004(.0005)$ & $.0003(.0004)$ \\
\hline Poverty gap, at $1.9 \$$ & $-.001(.001)$ & $.003(.003)$ & $-.013^{* * *}(.002)$ \\
\hline Access to electricity & $.002^{*}(.001)$ & $.014^{* * *}(.002)$ & $.006^{* * *}(.002)$ \\
\hline Mean years of education & $.131^{* * *}(.025)$ & $-.049(.045)$ & $-.100^{* *}(.041)$ \\
\hline Intercept & $3.003^{* * *}(.749)$ & $9.155^{* * *}(1.500)$ & $.228(1.051)$ \\
\hline \multicolumn{4}{|c|}{ Origin of the colonial power (categorical, ref. = not colonized): } \\
\hline Belgian & $-.702^{* * *}(.157)$ & $-1.744^{* * *}(.204)$ & $-1.275^{* * *}(.274)$ \\
\hline British & $-1.196^{* * *}(.105)$ & $-.830^{* * *}(.193)$ & $-.592^{* * *}(.160)$ \\
\hline French & $-1.114^{* * *}(.202)$ & $-2.371^{* * *}(.359)$ & $-.712^{* *}(.333)$ \\
\hline Portuguese & $-.561^{* * *}(.112)$ & $-.952^{* * *}(.204)$ & $.423^{*}(.211)$ \\
\hline Country dummy & $\checkmark$ & $\checkmark$ & $\checkmark$ \\
\hline Observations & 416 & 416 & 416 \\
\hline F-stat ( $p$-value) & $374.903(.000)$ & $274.091(.000)$ & $456.221(.000)$ \\
\hline Adj. R-Squared & .979 & .972 & .983 \\
\hline
\end{tabular}

Notes: Lag.lnGDP per capita and Life expectancy are the excluded instrumental variables used in the first stage. In bracket are bootstrapped standard errors. ${ }^{(* * *},{ }^{(* *)}$ and ${ }^{(*)}$ respectively stand for significance level at 1,5 and $10 \%$.

\section{- Using 4 years averaged data}

Although the cross-sectional characteristic of our panel dataset (41 countries) is larger than its time-series dimension (24), motivating standard panel data approach as proposed above, it matters to check our results relying on k-years averages. This process reduces the time span of the data and mitigates concerns that (non-) stationarity of the series involved in the analysis may be affecting the results. Using 4 -years averages, our conclusions are reviewed for robustness. The results of the latter procedure globally support our discussions regarding the link between human development, primary energy use and $\mathrm{CO}_{2}$ emissions as presented above (Table 7 ). 
Table 7. Regression Results using 4 years average data

\begin{tabular}{|c|c|c|c|}
\hline & \multicolumn{3}{|c|}{ Dependent variables: } \\
\hline & Human Development index & Primary energy use & $\mathrm{CO}_{2}$ emissions \\
\hline Lag.lnGDP per capita & $.043^{* * *}(.010)$ & & \\
\hline Life expectancy & $.007^{* * *}(.000)$ & & \\
\hline Spatial lag of energy use & & $.172^{*}(.103)$ & \\
\hline Human Development index & & $1.364^{*}(.727)$ & \\
\hline Spatial lag of $\mathrm{CO}_{2}$ & & & $.306^{* *}(.117)$ \\
\hline Primary Energy use & & & $.432^{* * *}(.081)$ \\
\hline Agriculture, GDP share & $-.002(.004)$ & $-.001(.006)$ & $.012^{* *}(.005)$ \\
\hline Industry, GDP share & $-.002(.004)$ & $.009(.006)$ & $-.004(.005)$ \\
\hline Rents of nat. resources & $.002(.003)$ & $-.011^{* *}(.004)$ & $.006(.004)$ \\
\hline FDI, net inflows & $-.001^{*}(.000)$ & $-.006(.005)$ & $-.004(.005)$ \\
\hline Imports, GDP share & $.001(.001)$ & $-.003^{*}(.002)$ & $.003^{*}(.002)$ \\
\hline Exports, GDP share & $-.005^{*}(.002)$ & $.006^{*}(.004)$ & $-.003(.003)$ \\
\hline Population growth & $.002(.020)$ & $-.056(.037)$ & $-.010(.035)$ \\
\hline Urban population growth & $-.002(.002)$ & $.011(.027)$ & $-.011(.025)$ \\
\hline Average Temperatures & $.017^{* *}(.007)$ & $.061(.110)$ & $.178^{*}(.103)$ \\
\hline Total rainfalls, yearly & $.003(.002)$ & $.001(.003)$ & $.001^{* *}(.000)$ \\
\hline Political stability & $-.005(.003)$ & $-.043(.052)$ & $-.002(.048)$ \\
\hline Riots incidence & $-.002(.004)$ & $.001(.001)$ & $.0004(.001)$ \\
\hline Poverty gap, at $1.9 \$$ & $-.001^{* * *}(.000)$ & $.005(.004)$ & $-.012^{* * *}(.003)$ \\
\hline Access to electricity & $.004 *(.002)$ & $.012^{* * *}(.003)$ & $.005(.003)$ \\
\hline Mean years of education & $.011^{* * *}(.004)$ & $-.137^{* *}(.067)$ & $-.169^{* * *}(.061)$ \\
\hline Intercept & $-.593^{* * *}(.167)$ & $11.75^{* * *}(3.086)$ & $-5.815^{* *}(2.450)$ \\
\hline \multicolumn{4}{|c|}{ Origin of the colonial power (categorical, ref. = not colonized): } \\
\hline Belgian & $-.043(.032)$ & $-2.178^{* * *}(.438)$ & $-1.461^{* *}(.576)$ \\
\hline British & $-.078^{* * *}(.018)$ & $-.637^{* *}(.294)$ & $-.076(.265)$ \\
\hline French & $-.181^{* * *}(.059)$ & $-2.245^{* *}(.941)$ & $-1.825^{*}(.928)$ \\
\hline Portuguese & $-.086^{* * *}(.028)$ & $-.675(.448)$ & $.016(.459)$ \\
\hline Country dummy & $\checkmark$ & $\checkmark$ & $\checkmark$ \\
\hline Observations & 184 & 184 & 184 \\
\hline F-stat ( $p$-value) & $84.564^{* * *}$ & $4.809^{* * *}$ & $7.170^{* * *}$ \\
\hline Adj. R-Squared & $0.918(.000)$ & $0.390(.000)$ & $0.488(.000)$ \\
\hline
\end{tabular}

Notes: Dependent variable for the first stage is the HDI. Lag.lnGDP per capita and Life expectancy are the excluded instrumental variables used in the first stage. Primary energy use and $\mathrm{CO}_{2}$ emissions are the dependent variables for the second and third stages. In bracket are bootstrapped standard errors. '***, ‘**, and ${ }^{* *}$ ' respectively stand for significance level at 1,5 and $10 \%$.

An exhaustive reading of the results of our recursive regression suggests that efforts of human development and of poverty alleviation drive fossil energy use and indirectly $\mathrm{CO}_{2}$ emissions in SSA. Since the empirical results indicate fossil energy use driving GHG emissions, any environmental policy aiming at reducing GHG emissions and related environmental consequences in SSA should target energy supply and demand.

In conclusion, the robustness analyses relying on an alternative indicator of human development, household final consumption expenditures, and using 4-years averaged data globally supports our primary discussions regarding the link between pollutant emissions, fossil energy use and human development. As the literature largely questions linearity in the $\mathrm{CO}_{2}$ emissions, energy and development nexus, we propose a non-parametric analysis of the core individual relationships. 


\subsection{A non-parametric perspective}

Assessing general patterns of the core individual relationships we discussed above, it is satisfactory to only focus on primary energy use and to provide insights into its overall behaviour to human development $(H D I)$ and household final consumption expenditures.

For this purpose, we use the local constant or Nadayara-Watson (NW) kernel estimation method, the aim of which is to directly estimate the functions $\mathrm{E}\left[E U_{i t} \mid H D I_{i t}\right]=m\left(H D I_{i t}\right)$ and $\mathrm{E}\left[E U_{i t} \mid H F C_{i t}\right]=n\left(H F C_{i t}\right)$, where $m($.$) and$ $n($.$) are non-parametric functions. Using the Nadayara-Watson estimator, we rely$ on the Silverman's rule-of-thumb bandwidth. Doing so, we obtain results clarifying interrogations concerning linearity in the energy and human development relationship. Figures 4, 5 and 6 below depict the results of the non-parametric regression.

Overall, primary energy use per capita shows an increasing relationship to human development index, implying that the higher the level of development, the larger the demand for energy and consequently fossil energy consumption in SSA. The corresponding (heteroscedasticity-robust) confidence intervals indicate that the observed upward trend is statistically significant. The latter patterns (Figure 4) support the linear specification used throughout this paper, in addition to invalidating the Environmental Kuznets Curve hypothesis for SSA countries. The alternative indicator of living conditions, household final consumption, shows comparable patterns to primary energy use (Figure 5). Globally, our parametric and non-parametric analyses fairly indicate that efforts of improving living conditions mainly drive fossil energy use.

Carbon dioxide emissions primarily resulting from fossil energy consumption, increasing patters in $\mathrm{CO}_{2}$ emissions are to associate with the growing primary energy use observed in SSA. As expected, the non-parametric result shows an upward trend between primary energy use and GHG emissions (Figure 6). This suggests that as long as the energy demand driven by efforts of improving living conditions is compensated by fossil energies, $\mathrm{CO}_{2}$ emissions will be increasing in SSA. Therefore, environmental policies aiming at reducing $\mathrm{CO}_{2}$ emissions in SSA should be promoting less polluting and renewable energies consumption as well as energy efficiency. 


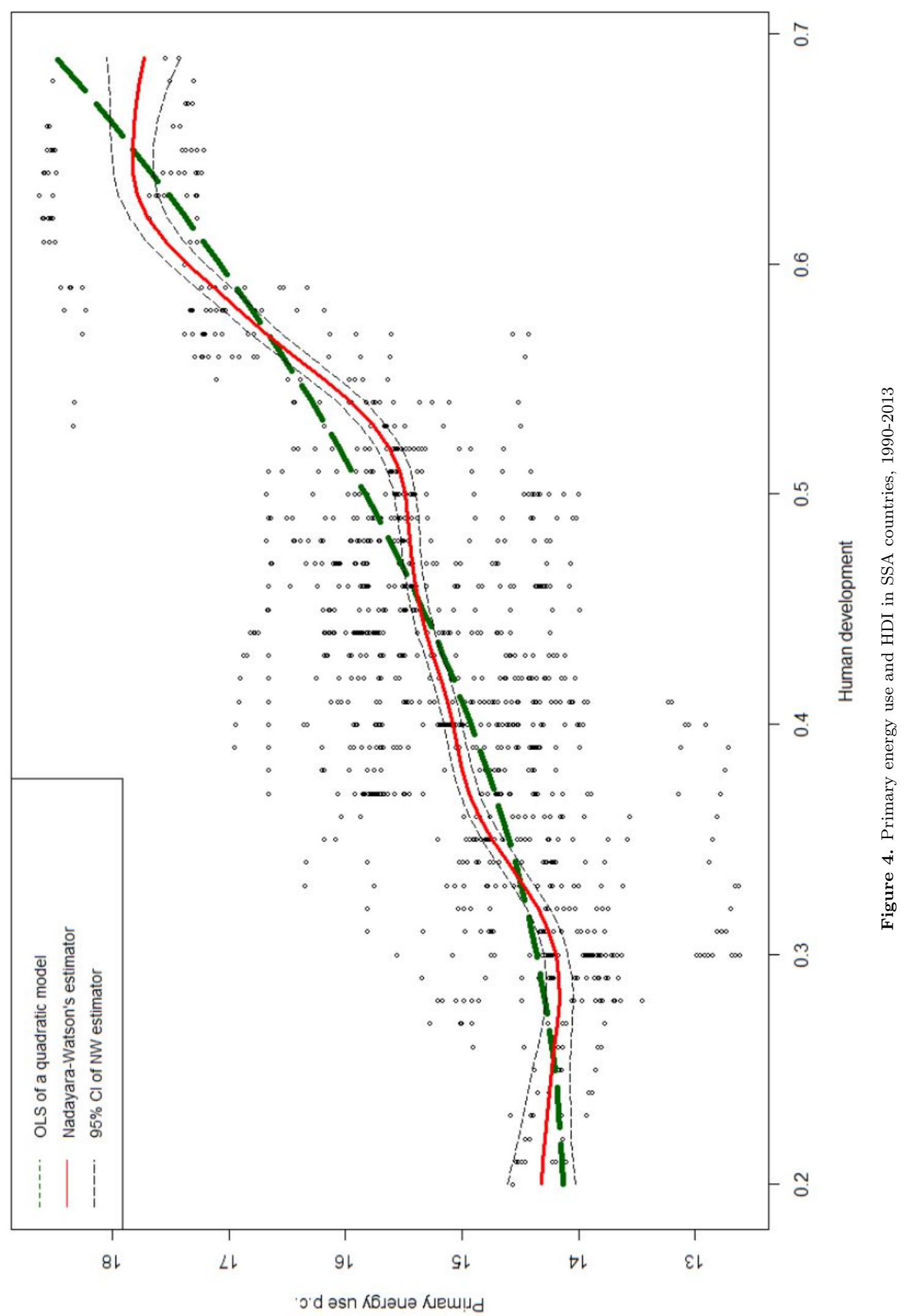




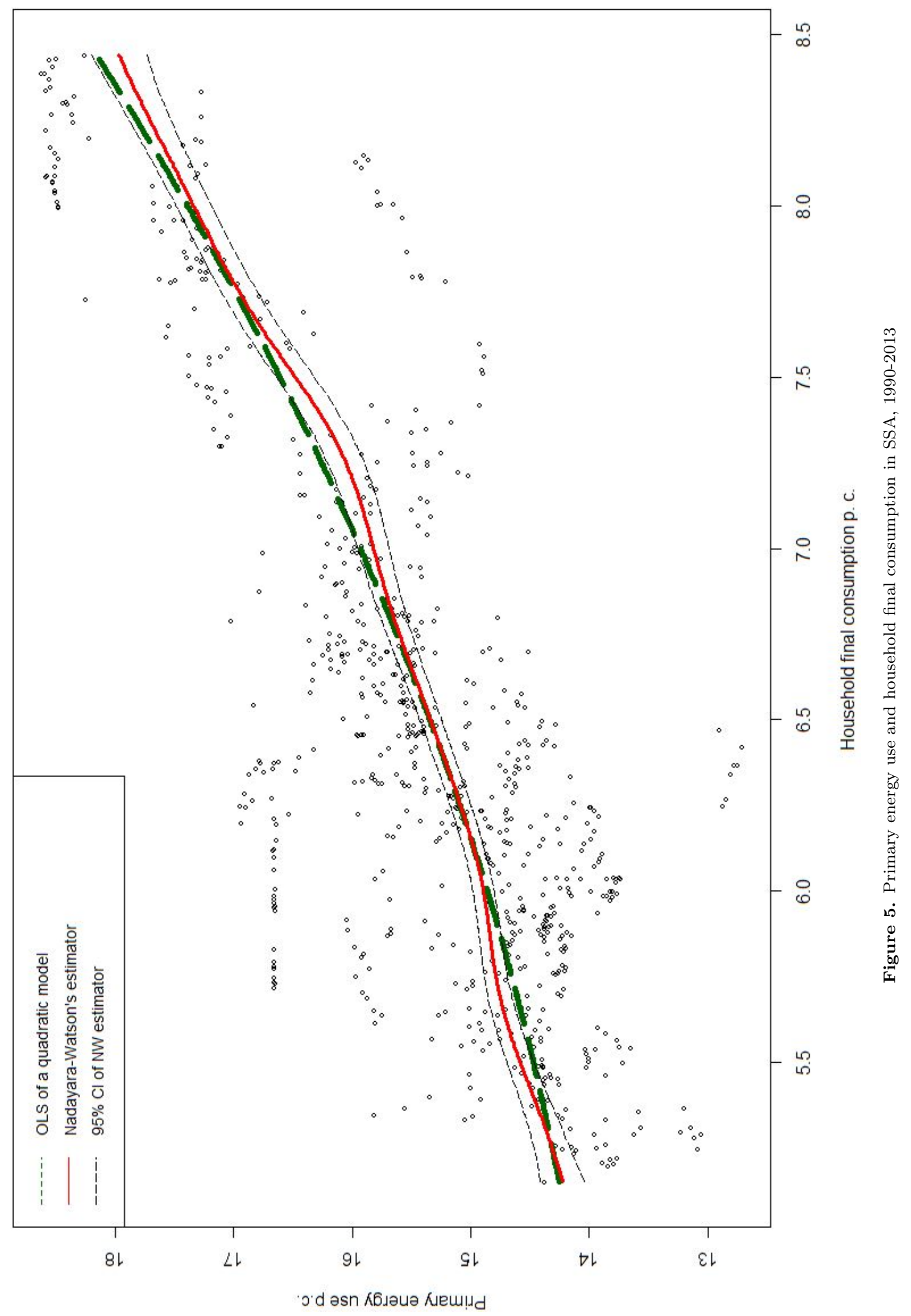




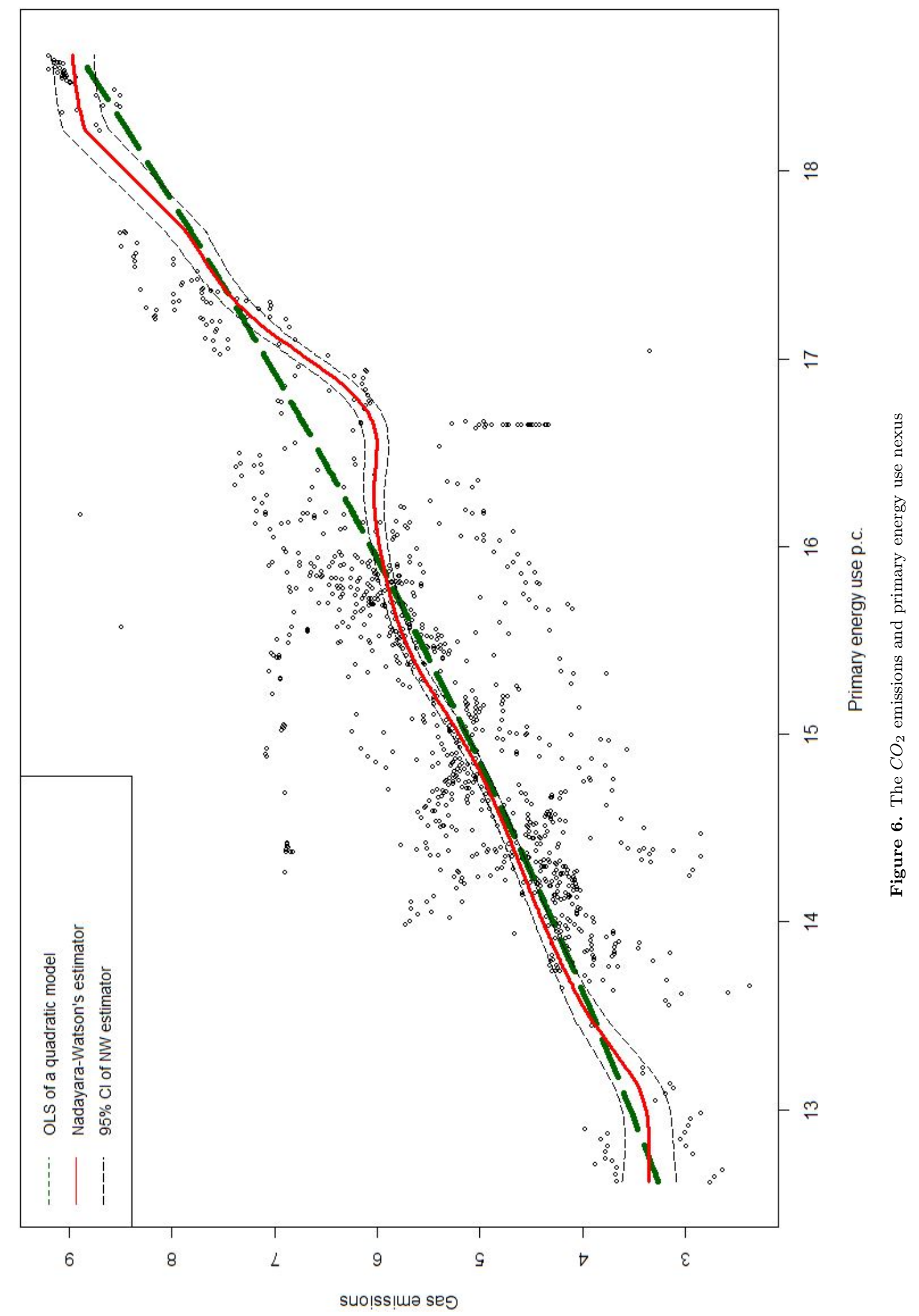




\section{Concluding Remarks}

This paper assesses the relationship between carbon dioxide emissions, primary energy use and human well-being in SSA countries, arguing that economic growth does not directly and systematically promote $\mathrm{CO}_{2}$ emissions, fossil energy consumption does. Hence, contrary to existing studies (EKC and causality analyses) linking GHG emissions to economic growth, our analysis proposes to model $\mathrm{CO}_{2}$ emissions as directly resulting from primary energy use, the latter being promoted by efforts of improving living conditions. We address further shortcomings of existing studies such as geographical spillovers, qualitative measures of economic development (HDI) and historical considerations.

Using a recursive specification, we derive results of a first stage regression indicating that income level, education, life expectancy and access to electricity improve human development in Africa. In accordance with the comparative development literature, we control for colonial history of SSA countries and find results supporting perspectives on the colonial origins of comparative development. Specifically, our analysis suggests that being a former colony negatively impacts human development in African countries. Since current political institutions in SSA countries mostly derive from colonial and extractive institutions, they produce relatively poor performances in terms of education, life expectancy and standard of living.

Regarding the drivers of energy use, our analysis indicates that efforts of improving human well-being principally lead to primary energy use. Socio-economic characteristics of SSA countries such as population growth and access to electricity are found to promote energy demand, thus primary energy use in SSA. Based on this, we can state that fossil energy consumption notably results from energy demand (due to access to electricity) and efforts of improving living conditions. Concerning GHG emissions, the results support our argument in identifying $\mathrm{CO}_{2}$ emissions as a direct consequence of fossil energy use in SSA, rather than economic development. As neighbouring SSA countries show similar geographical characteristics and correlated intensities in primary energy use, it is not surprising to observe positive and significant geographical spillovers in GHG emissions across SSA. A comprehensive reading of the outcomes of our recursive analysis consists in concluding that $\mathrm{CO}_{2}$ emissions in SSA are direct consequences of fossil energy use, the latter being promoted by efforts of improving living conditions. Such a conclusion also applies to post-industrial societies, as long as energy demand resulting from efforts of improving well-being is compensated by fossil energies.

The present paper questions studies analysing causality between economic growth and GHG emissions, holding economic growth responsible for environmental pollution. It rather argues for a recursive mechanism between GHG emissions, energy and human development. Hence, in terms of environmental strategy for Africa, instead of a de-growth, this study suggests reducing fossil energy use. This implies for SSA further effort towards energy efficiency and more largely a transition from traditional and fossil to less polluting and renewable energies. Indeed, improving human well-being is a priority in SSA. Nonetheless, environmental degradation and climate change threaten the future of African societies if not dealt with. Therefore, SSA countries are encouraged to tackle the issue of increasing GHG emissions at its source by fostering private and public initiatives and investments in renewable energies and energy saving 
technologies.

\section{References}

Acemoglu, D., Johnson, S., Robinson, J.A., 2001. The colonial origins of comparative development: An empirical investigation. Am. Econ. Rev. 91, 1369-1401.

Acemoglu, D., Johnson, S., Robinson, J.A., 2012. The colonial origins of comparative development: An empirical investigation: Reply. Am. Econ. Rev. 102, 3077-3110.

Africa Energy Outlook, I., 2019. Africa energy outlook 2019: World energy outlook special report. https://www.iea.org/reports/africa-energy-outlook-2019.

Aglina, M.K., Agbejule, A., Nyamuame, G.Y., 2016. Policy framework on energy access and key development indicators: Ecowas interventions and the case of Ghana. Energy Policy 97, 332-342.

Aldy, J., 2007. Energy and carbon dynamics at advanced stages of development: An analysis of the US States, 1960-1999. Energy J. 28, 91-111.

Arbex, M. Perobelli, F.S., 2010. Solow meets Leontief: Economic growth and energy consumption. Energy Econ. 32, 43-53.

Arto, I., Capellán-Pérez, I., Lago, R., Bueno, G., Bermejo, R., 2016. The energy requirements of a developed world. Energy Sustain. Dev. 33, 1-13.

Azomahou, T.T., Goedhuys, M., Van, P.N., 2016. A structural nonparametric reappraisal of the co2 emissions-income relationship. Revue Econ. 67, 167-174.

Bedir, S. Yilmaz, V.M., 2016. CO2 emissions and human development in OECD countries: Granger causality analysis with a panel data approach. Eurasian Econ. Rev. 6, 97-110.

Conti, J., Holtberg, P., Diefenderfer, J., LaRose, A., Turnure, J., Westfall, L., 2016. International energy outlook 2016 with projections to 2040. Washington, DC, USA: US Energy Information Administration (EIA).

Dato, P., 2017. Energy transition under irreversibility: A two-sector approach. Environ. Resour. Econ. 68(3), 797-820.

Dones, R., Heck, T., Hirschberg, S., 2004. Greenhouse gas emissions from energy systems: Comparison and overview. Technical Report CH-0401.

Eliasson, L. Turnovsky, S.J., 2004. Renewable resources in an endogenously growing economy: Balanced growth and transitional dynamics. J. Environ. Econ. Manage. 48, 1018-1049.

Eskeland, G.S. Harrison, A.E., 2003. Moving to greener pastures? Multinationals and the pollution haven hypothesis. J. Dev. Econ. 70(1), 1-23.

Gassebner, M., Lamla, M.J., Sturm, J.E., 2010. Determinants of pollution: What do we really know? Oxford Econ. Pap. 63, 568-595.

Grossman, G.M. Krueger, A.B., 1991. Environmental impacts of a North American free trade agreement. Technical Report 3914 National Bureau of Economic Research.

Grossman, G.M. Krueger, A.B., 1995. Economic growth and the environment. The Q. J. Econ. 110(2), 353-377.

Halicioglu, F., 2009. An econometric study of $\mathrm{CO} 2$ emissions, energy consumption, income and foreign trade in Turkey. Energy Policy 37(3), 1156-1164.

Huang, B.N., Hwang, M.J., Yang, C.W., 2008. Causal relationship between energy consumption and GDP growth revisited: A dynamic panel data approach. Ecolog. Econ. 67, 41-54.

Joyeux, R. Ripple, R., 2011. Energy consumption and real income: A panel cointegration multi-country study. Energy J. 32, 107-142. 
Kazar, G. Kazar, A., 2014. The renewable energy production-economic development nexus. Int. J. Energy Econ. Policy 4, 312-319.

Lawson, L.A. Nguyen-Van, P., 2020. Institutions and geography: A "two sides of the same coin" story of primary energy use in Sub-Saharan Africa. Energy J. 42.

Liddle, B., 2013. The energy, economic growth, urbanization nexus across development: Evidence from heterogeneous panel estimates robust to cross-sectional dependence. Energy J. $34,223-244$.

Mardani, A., Streimikiene, D., Cavallaro, F., Loganathan, N., Khoshnoudi, M., 2019. Carbon dioxide (co2) emissions and economic growth: A systematic review of two decades of research from 1995 to 2017. Sci. Total Environ. 649, 31-49.

Martinez, D.M. Ebenhack, B.W., 2008. Understanding the role of energy consumption in human development through the use of saturation phenomena. Energy Policy. 36, 14301435.

Martínez-Zarzoso, I. Maruotti, A., 2011. The impact of urbanization on CO2 emissions: Evidence from developing countries. Ecolog. Econ. 70, 1344-1353.

Melo, L., Quinn, M.A., et al., 2015. Oil, foreign direct investment and corruption. The International Journal of Business and Finance Research 9(1), 33.

Nguyen, V.T., Van Tran, Q., Do, L.T.T., Dinh, L.H., Do, H.T.T., 2019. Trade off between environment, energy consumption and human development: Do levels of economic development matter? Energy 173, 483-493.

Nguyen-Van, P., 2010. Energy consumption and income: A semiparametric panel data analysis. Energy Econ. 32, 557-563.

Niu, S., Jia, Y., Wang, W., He, R., Hu, L., Liu, Y., 2013. Electricity consumption and human development level: A comparative analysis based on panel data for 50 countries. Int. J. Electr. Power Energy Syst. 53, 338-347.

Nunn, N., 2009. The importance of history for economic development. Annu. Rev. Econom. $1,65-92$.

Omri, A., 2013. Co2 emissions, energy consumption and economic growth nexus in MENA countries: Evidence from simultaneous equations models. Energy Econ. 40, 657-664.

Ouedraogo, N.S., 2013. Energy consumption and human development: Evidence from a panel cointegration and error correction model. Energy 63, 28-41.

Ozturk, I., 2010. A literature survey on energy-growth nexus. Energy Policy 38, 340-349.

Pasternak, A.D., 2000. Global energy futures and human development: A framework for analysis. US Department of Energy, Oak Ridge.

Pîrlogea, C., 2012. The human development relies on energy: Panel data evidence. Procedia Econ. Financ. 3, 496-501.

Rafindadi, A.A. Usman, O., 2019. Globalization, energy use, and environmental degradation in South Africa: Startling empirical evidence from the Maki-cointegration test. J. Environ. $244,265-275$.

Rahman, M.M., 2020. Environmental degradation: The role of electricity consumption, economic growth and globalisation. J. Environ. 253, 109742.

Ross, M.L., 2015. What have we learned about the resource curse. Annual Review of Political Science 18, 239-259.

Roy, H., Jayaraj, R., Gupta, A., 2015. Energy consumption and human development: Global perspective. Econ. Policy Energy Environ. 2015, 111-131.

Satrovic, E., 2018. The human development relies on renewable energy: Evidence from Turkey. 3rd International Energy and Engineering, in: Book of Proceedings, Gaziantep, Turkey pp. 
19-27.

Shafik, N. Bandyopadhyay, S., 1992. Economic growth and environmental quality: Time-series and cross-country evidence volume 904. World Bank Publications.

Soukiazis, E., Proenca, S., Cerqueira, P.A., 2019. The interconnections between renewable energy, economic development and environmental pollution: A simultaneous equation system approach. Energy J. 40(4).

Steinberger, J.K. Roberts, J.T., 2010. From constraint to sufficiency: The decoupling of energy and carbon from human needs, 1975-2005. Ecological Economics 70(2), 425-433.

Stern, D.I. Cleveland, C.J., 2004. Energy and economic growth. Rensselaer Working Papers in Economics 0410, 1-42.

Sy, A., 2016. Africa: Financing adaptation and mitigation in the world's most vulnerable region. Africa: Brookings Institution, Africa Growth Initiative.

Tiba, S. Omri, A., 2017. Literature survey on the relationships between energy, environment and economic growth. Renew. Sust. Energ. Rev. 69, 1129-1146.

Tobler, W.R., 1970. A computer movie simulating urban growth in the Detroit region. Econ. Geogr. 46, 234-240.

UNDP, 2019. Human Development Index (hdi) - Human Development Reports.

United Nations, U., 1997. Glossary of environment statistics, studies in methods.

Van der Ploeg, F. Withagen, C., 2012. Is there really a green paradox? J. Environ. Econ. Manag. 64(3), 342-363.

Wang, Z., Zhang, B., Wang, B., 2018. Renewable energy consumption, economic growth and human development index in Pakistan: Evidence form simultaneous equation model. $J$. Clean. Prod. 184, 1081-1090.

WDI, 2019. World Development Indicators Database, assessed online on 7 August 2019.

World Bank, W., 2020. Wdi: Renewable energy consumption in Sub-Saharan Africa. https://data.worldbank.org/indicator/EG.FEC.RNEW.ZS?locations=ZG.

Wu, Q., Clulow, V., Maslyuk, S., 2010. Energy consumption inequality and human development. In 2010 International Conference on Management Science \& Engineering 17th Annual Conference Proceedings pp. 1398-1409. IEEE.

You, W.H., Zhu, H.M., Yu, K., Peng, C., 2015. Democracy, financial openness, and global carbon dioxide emissions: Heterogeneity across existing emission levels. World Devel. 66, 189 207. 


\section{Supplementary Materials}

Table A.1. Standard Hausman Test

\begin{tabular}{lccccc|ccc}
\hline \hline & \multicolumn{2}{c}{ In models for HDI } & \multicolumn{2}{c}{ In models for Energy use } & \multicolumn{2}{c}{ In models for Co2 } \\
\cline { 2 - 3 } \cline { 7 - 8 } Yearly waves & $\chi^{2}$ & $p$-value & & $\chi^{2}$ & $p$-value & & $\chi^{2}$ & $p$-value \\
\hline Model I & 77.573 & .000 & & 121.80 & .000 & & 25.975 & .000 \\
Model II & 2.988 & .000 & 32.437 & .000 & & 33.939 & .000 \\
Model III & 9.272 & .319 & 4.120 & .000 & & 37.357 & .000 \\
Model IV & 15.32 & .000 & & 41.068 & .000 & & 24.91 & .000 \\
Model V & 24.497 & .010 & & 33.029 & .011 & & 101.84 & .000 \\
\hline \hline
\end{tabular}

Note: The test evaluates the consistency of the fixed-effects (FE) estimator when compared to a randomeffects (RE) specification. Under the null-hypothesis there should be no systematic difference between the two estimators.

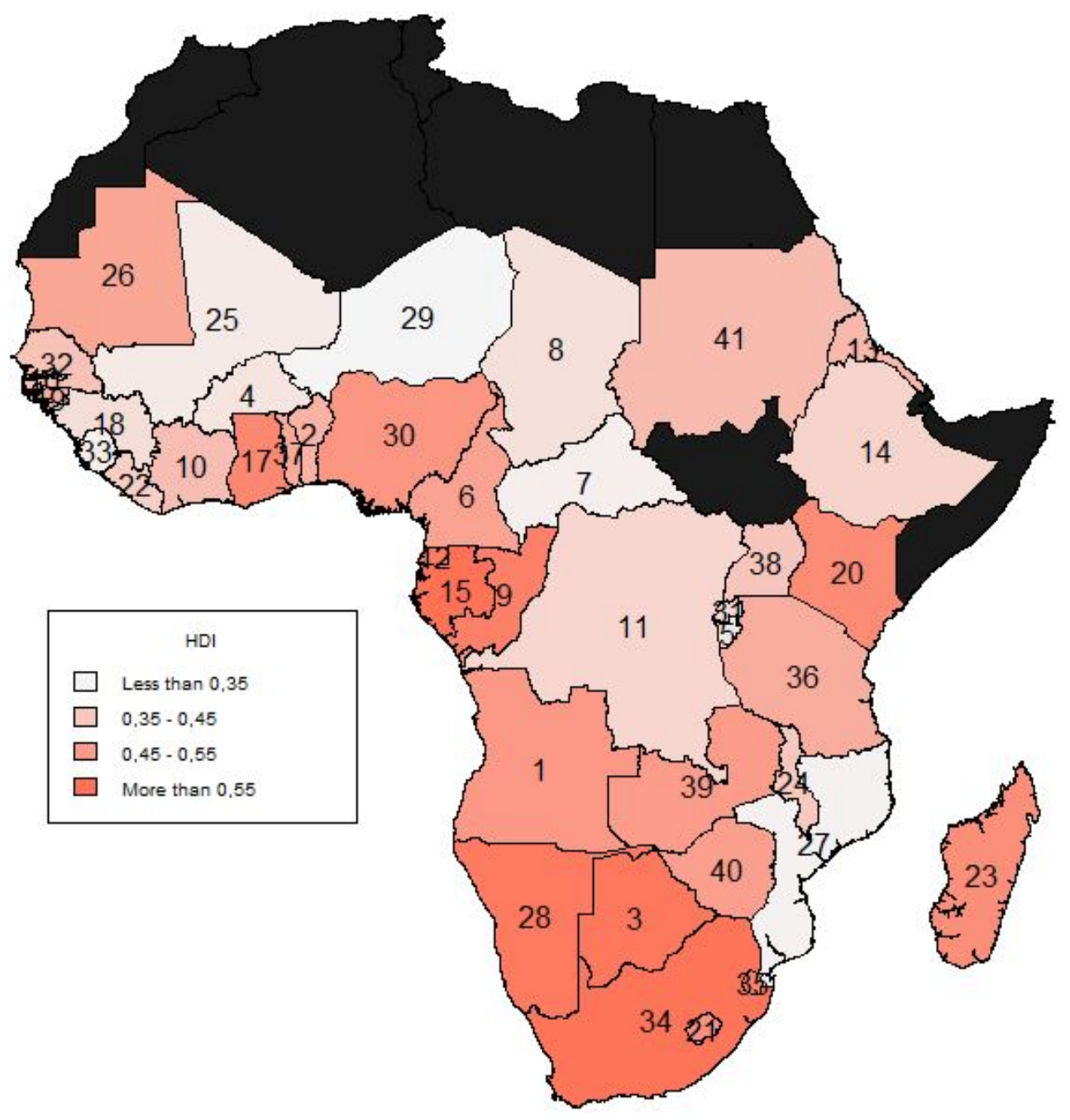

Figure A.1. Human Development Index in SSA 


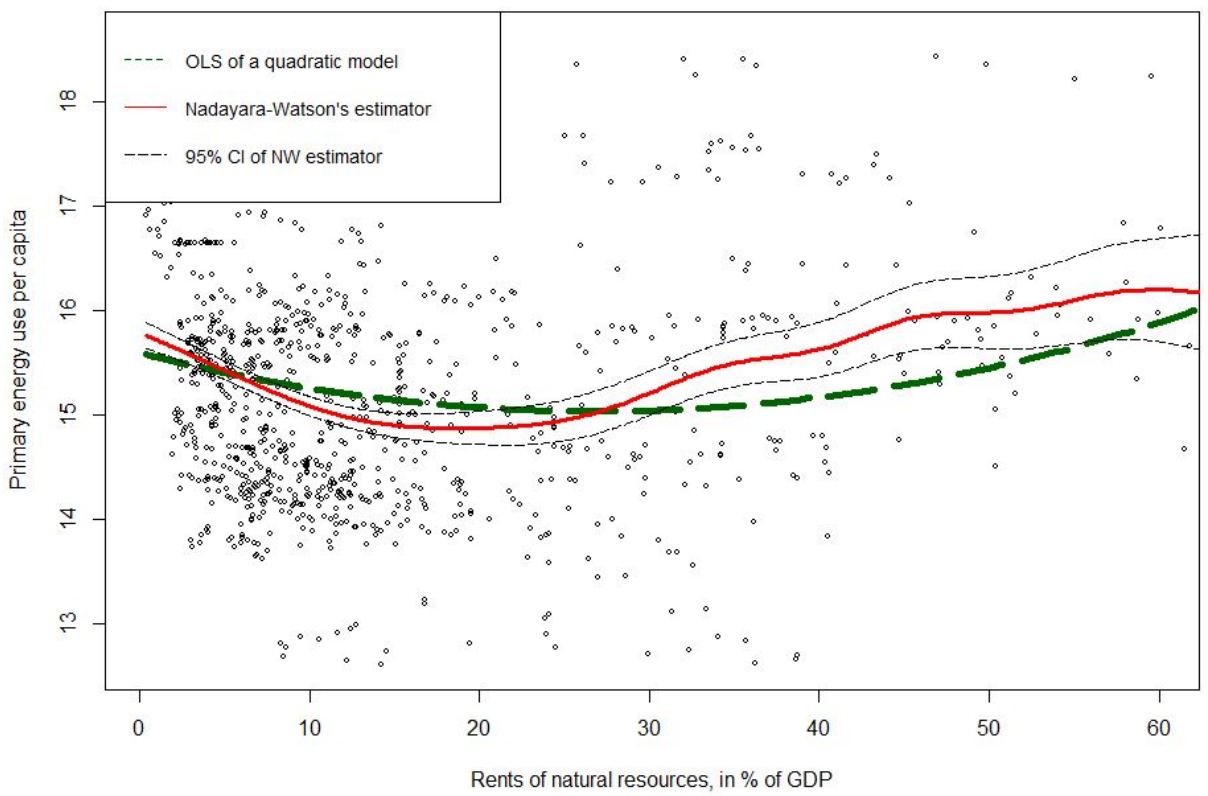

Figure A.2. Primary energy use and natural resources rents in SSA, 1990-2013

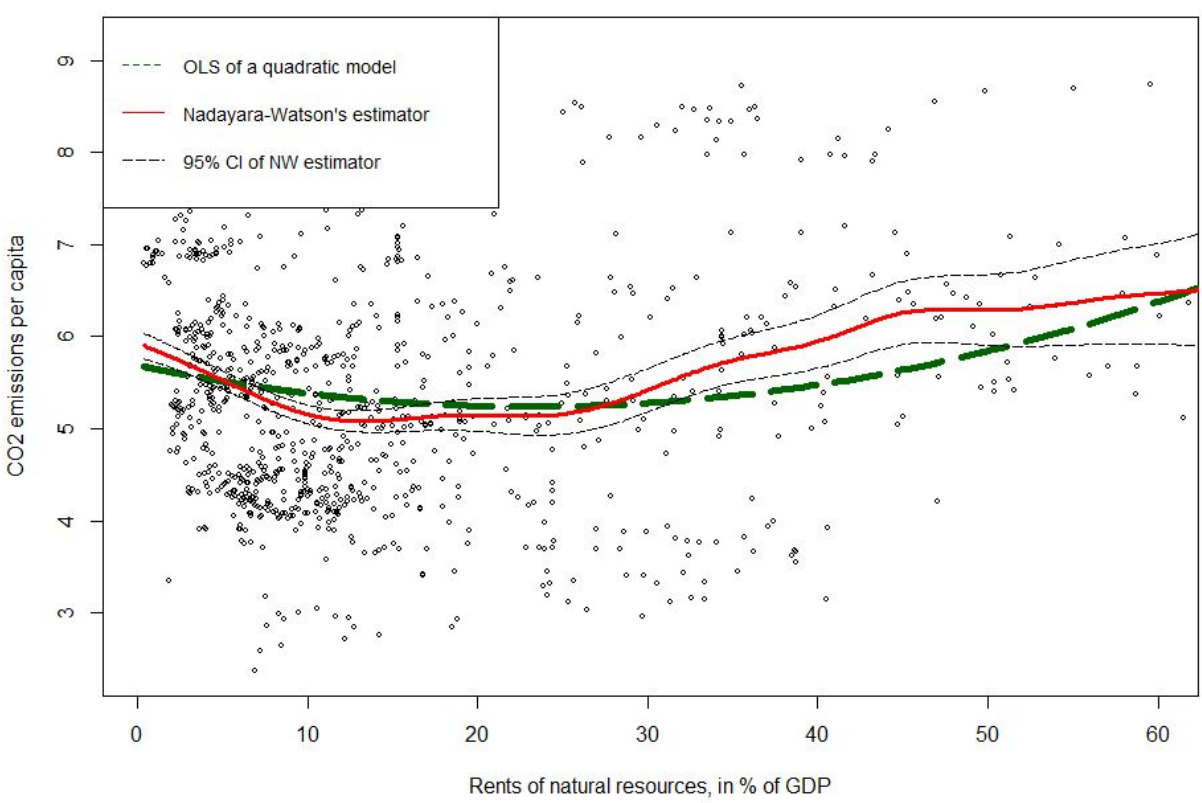

Figure A.3. CO2 emissions and natural resources rents in SSA countries, 1990-2013

Note: Assessing each of these individual relationships, we ignored the very few observations on the right of the natural resource rents i.e. very high values of resource rents in GDP. This explains why the highest value of resource rents in GDP is constrained to $60 \%$. 


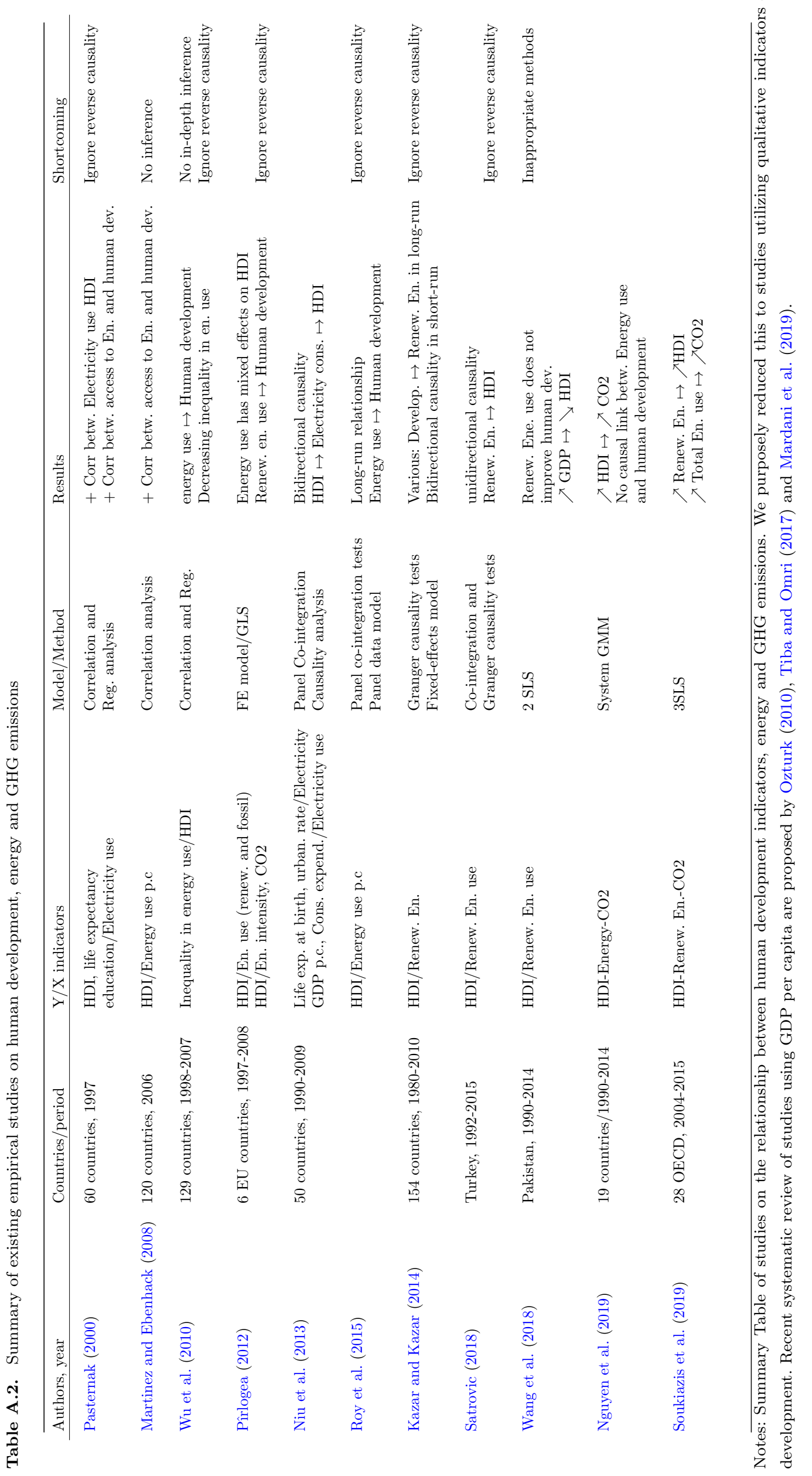




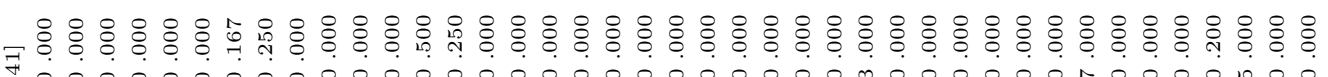

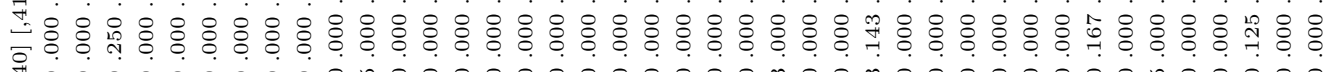

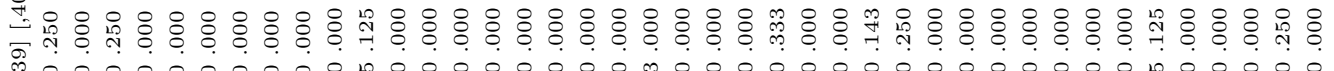
\%

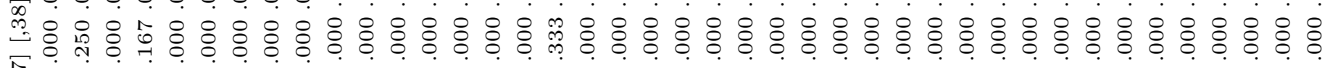

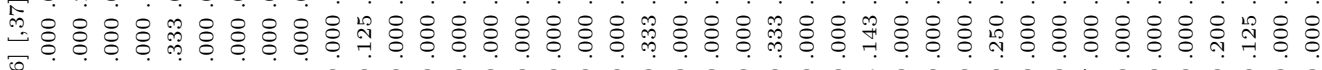

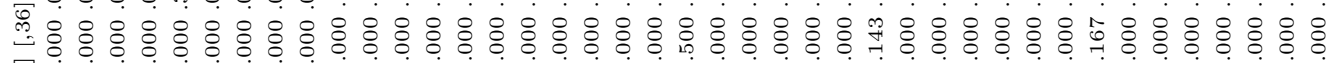

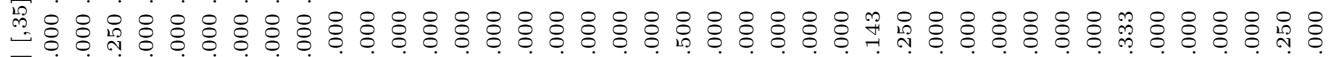
寻官 䎂

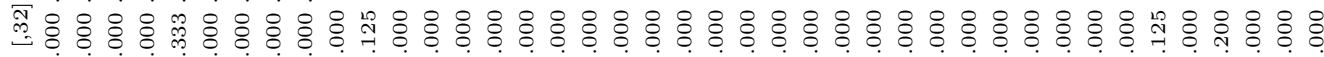

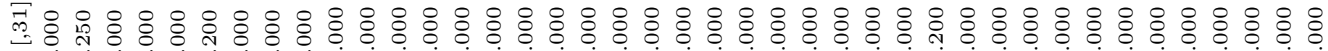

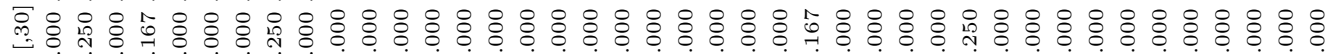
承离

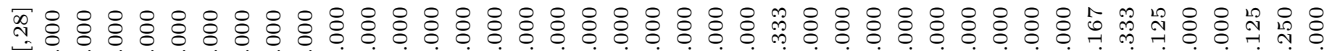

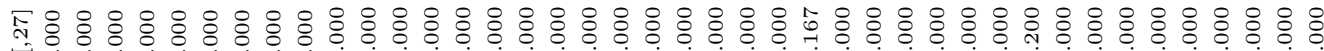

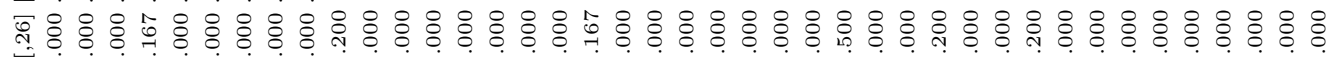

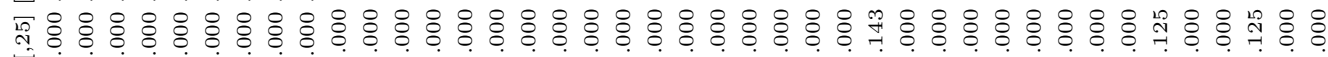
齐

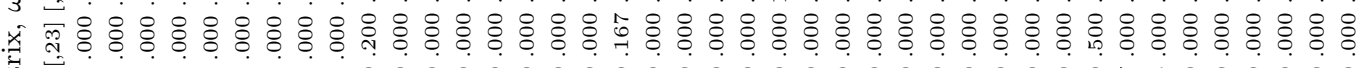

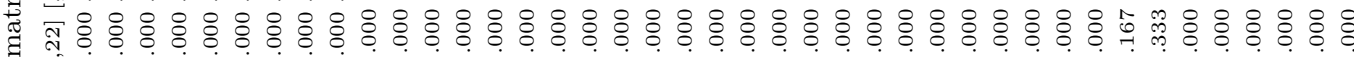

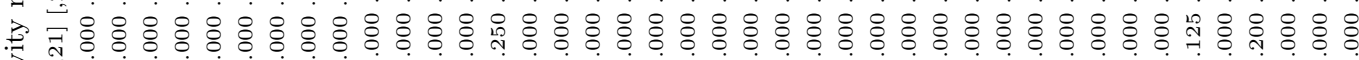
家

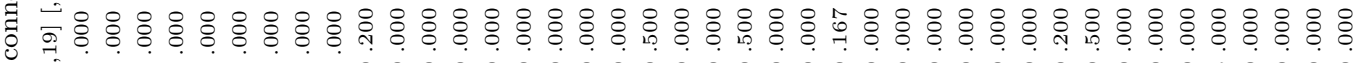
๘ 帝

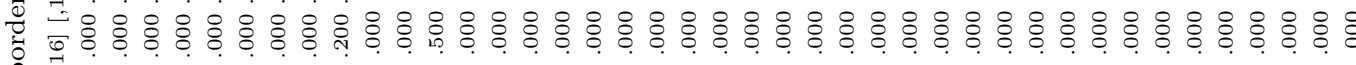

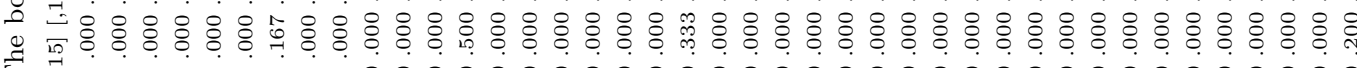
苂 安

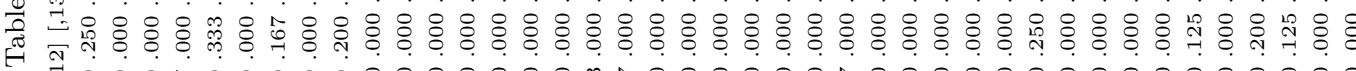

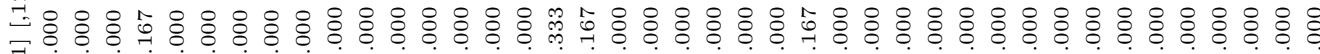
ت \% б

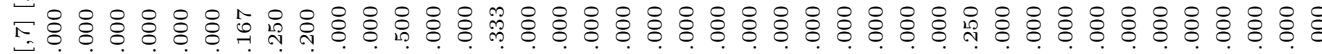

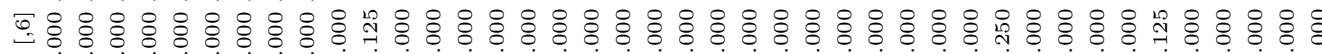

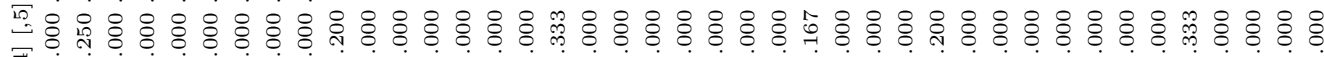

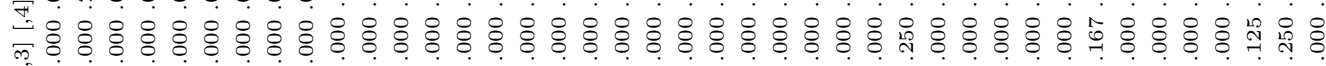

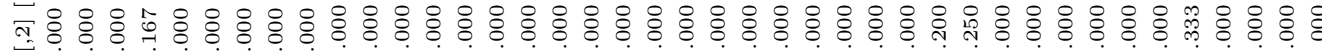

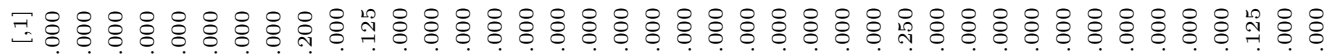

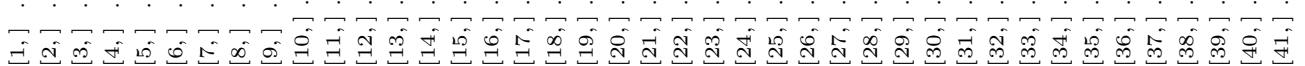




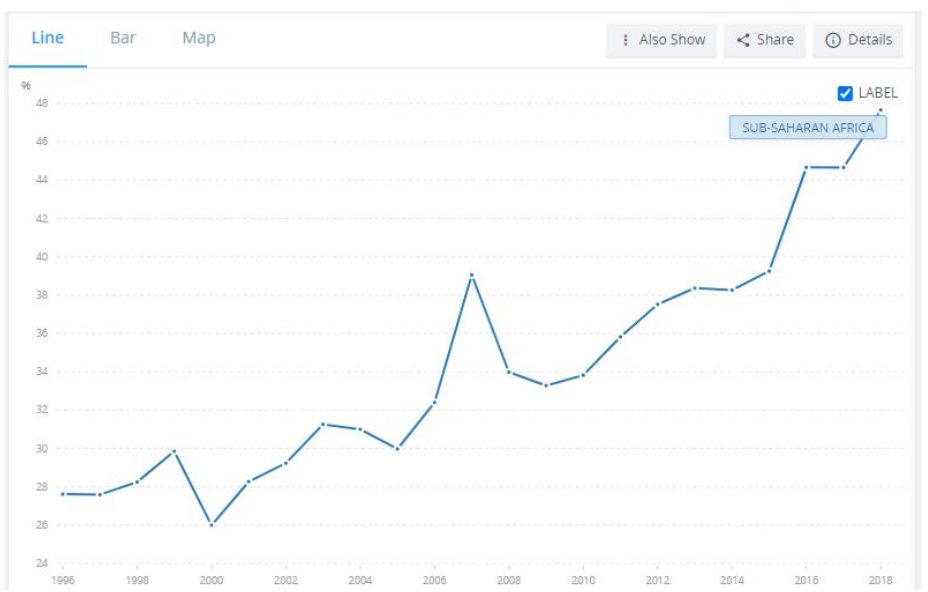

Figure A.4. Access to electricity (\% of population) - Sub-Saharan Africa

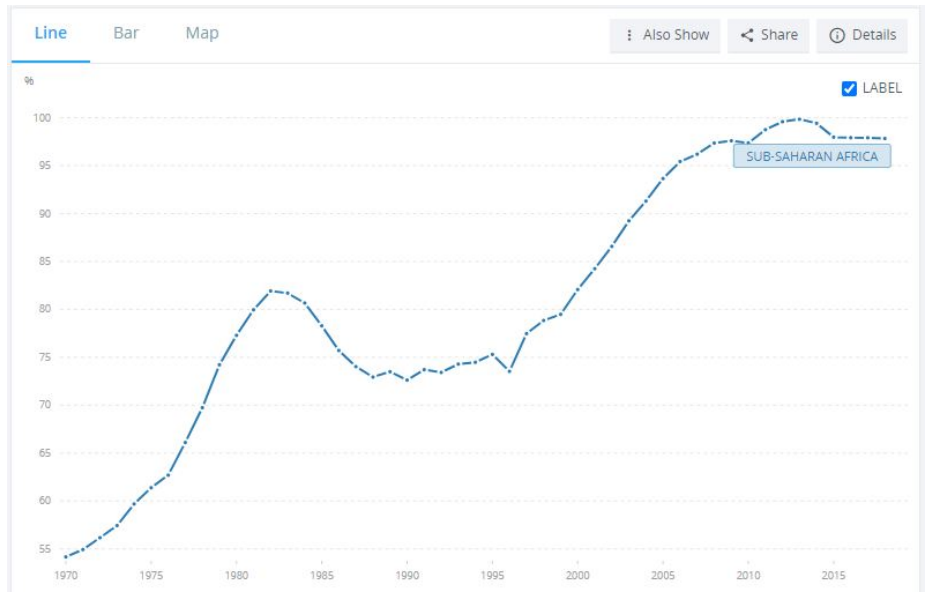

Figure A.5. School enrollment, primary (\% gross) - Sub-Saharan Africa

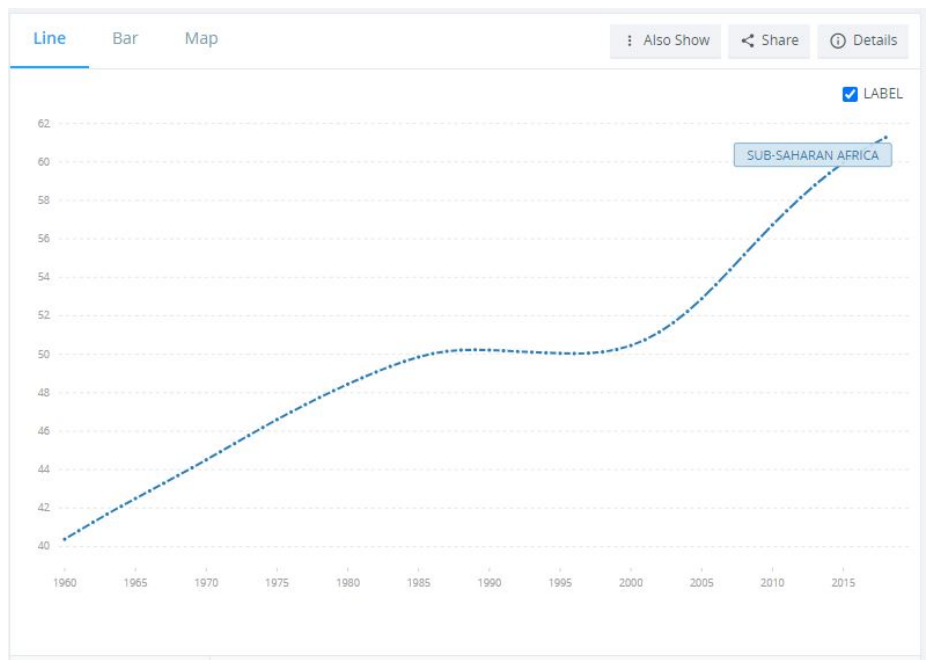

Figure A.6. Life expectancy at birth, total (years) - Sub-Saharan Africa

Source: World Bank Data accessed on 06 June, 2020. See respectively for SM2, SM3 and SM4 